\title{
"Incorporating creditors' seniority into contingent claim models: Application to peripheral euro area countries"
}




\section{$\boxplus|R| E|A|$}

Institut de Recerca en Economia Aplicada Regional i Pública

Research Institute of Applied Economics

Universitat de Barcelona

Av. Diagonal, $690 \bullet 08034$ Barcelona

WEBSITE: www.ub.edu/irea/•CONTACT: irea@ub.edu

The Research Institute of Applied Economics (IREA) in Barcelona was founded in 2005, as a research institute in applied economics. Three consolidated research groups make up the institute: AQR, RISK and GiM, and a large number of members are involved in the Institute. IREA focuses on four priority lines of investigation: (i) the quantitative study of regional and urban economic activity and analysis of regional and local economic policies, (ii) study of public economic activity in markets, particularly in the fields of empirical evaluation of privatization, the regulation and competition in the markets of public services using state of industrial economy, (iii) risk analysis in finance and insurance, and (iv) the development of micro and macro econometrics applied for the analysis of economic activity, particularly for quantitative evaluation of public policies.

IREA Working Papers often represent preliminary work and are circulated to encourage discussion. Citation of such a paper should account for its provisional character. For that reason, IREA Working Papers may not be reproduced or distributed without the written consent of the author. A revised version may be available directly from the author.

Any opinions expressed here are those of the author(s) and not those of IREA. Research published in this series may include views on policy, but the institute itself takes no institutional policy positions. 
This paper highlights the role of multilateral creditors (i.e., the ECB, IMF, ESM etc.) and their preferred creditor status in explaining the sovereign default risk of peripheral euro area (EA) countries. Incorporating lessons from sovereign debt crises in general, and from the Greek debt restructuring in particular, we define the priority structure of sovereigns' creditors that is most relevant for peripheral EA countries in severe crisis episodes. This new priority structure of creditors, together with the contingent claims methodology, is then used to derive a set of sovereign credit risk indicators. In particular, the sovereign distance-to-default indicator, proposed in this paper (which includes both accounting metrics and market-based measures) aims to isolate sovereign credit risk by using information from the public sector balance sheets to build it up. Analyzing and comparing it with traditional market-based measures of sovereign risk suggests that the measurement and predictive ability of credit risk measures can be vastly improved if we account for the changing composition of sovereigns' balance sheet risk based on creditors' seniority.

JEL classification: E62, H3, C11

Keywords: Sovereign default risk, peripheral euro area countries, contingent claims, distance-to-default

Marta Gómez-Puig: Risckcenter Research group-IREA. Av. Diagonal 696; 08034 Barcelona ,Spain. E-mail: marta.gomezpuig@ub.edu

Manish K. Singh: Risckcenter Research group-IREA. Av. Diagonal 696; 08034 Barcelona ,Spain. E-mail: manish.singh@ub.edu

Simón Sosvilla-Rivero: Complutense Institute for International Studies, Universidad Complutense de Madrid; 28223 Madrid, Spain. E-mail: sosvilla@ccee.ucm.es

\section{Acknowledgements}

We are very grateful to seminar participants at the University of Barcelona for helpful comments and suggestions, to the Comision Nacional del Mercado de Valores for kindly providing the sovereign debt volatility dataset, to Analistas Financieros Internacionales for providing the CDS, yields and credit rating dataset, Vito Polito and Michael R. Wickens for providing the datasets of their Fiscal Stability Indicator and Fernando Fernández-Rodríguez for his research assistance. This paper is based on work supported by the Instituto de Estudios Fiscales [grant IEF 151/2017], the Bank of Spain [grant PR71/15-20229] and the Spanish Ministry of Economy and Competitiveness [grant ECO2016-76203C2-2-P]. Simon Sosvilla-Rivero thanks the Department of Economics at the University of Barcelona for their hospitality. The opinions expressed in this paper are those of the authors, and they do not reflect in any way those of the institutions to which they are affiliated. Responsibility for any remaining errors rests with the authors. 


\section{Introduction}

The global financial crisis, which began in the US in 2007, and the subsequent European sovereign debt crises of late 2009 have increased the need to understand and measure the sovereign credit risk of euro area (EA) countries. Understanding the nature of this risk is of paramount importance given the ever increasing size of the public debt in EA. However, empirical researchers find it difficult to reconcile the evolution of traditional market-based measures of sovereign risk in EA countries with their economic fundamentals (see De Grauwe (2012), De Grauwe and Ji (2013), Favero and Missale (2012), Aizenman et al. (2013), Beirne and Fratzscher (2013), among others). Also relevant is the feature unique to the EA according to which, unlike emerging countries or other developed economies, individual EA countries have no control over the currency in which their debt is denominated. This loss of control over their own currency and increased dependence on a common central bank (the European Central Bank (ECB)) makes countries fragile and vulnerable to changing market sentiments (see De Grauwe (2012)).

In this paper, we show that, if properly accounted for, an important element - the total debt held by multilateral creditors $^{1}$-, can reconcile some of the differences and improve the effectiveness of sovereign risk measures. Given the nature of the rescue and bail-out strategies, more and more debt is concentrating in the hands of multilateral institutions that are likely to have 'senior status'" in case of insolvency. To incorporate this, we propose a modified contingent claims model that takes into account the creditors' seniority, as observed in the sovereign debt restructuring of the past and integrates the lessons learned from the recent Greek debt restructuring, in order to derive a new set of sovereign credit risk indicators.

Why another sovereign credit risk indicator? Sovereign credit risk indicators are measures of governments' ability to repay their debt. In the context of EA, which has recently faced a fierce sovereign debt crisis, the choice of the optimal indicator is crucial. The amount of credit risk measured by these indicators may directly affect the behaviour of financial market participants when diversifying the risk of their global debt portfolios and may have major implications on financial stability. Moreover, they have a key role in determining the financing costs of the public sector since higher perceived risk implies higher long-term domestic interest rates, which in turn increase debt servicing costs and future government deficits.

Yet, according to the empirical literature, the traditional market-based sovereign credit risk indicators (sovereign yield spreads, credit default swap (CDS) spreads and credit ratings) in times of crisis are mainly driven by factors other than the fiscal stance (see Fontana and Scheicher (2016)). The most commonly used measures of sovereign credit risk are CDS contracts. However, CDS contracts that reference sovereign bonds are only a small part of

\footnotetext{
${ }^{1}$ The ECB, the European Financial Stability Facility (EFSF), the European Stability Mechanism (ESM), the International Monetary Fund (IMF), the European Investment Bank (EIB), etc.

${ }^{2}$ 'Senior status' means that the preferred lender is the first to recover its money in case of insolvency. The subordinated creditor, or junior creditor, on the other hand, receives only what is left after senior claim holders have been repaid
} 
the sovereign debt market in EA ( $\$ 3$ trillion notional sovereign CDS outstanding at end-June 2012, compared with $\$ 50$ trillion of government debt outstanding at end-2011: International Monetary Fund (2013)). Moreover, these contracts are thinly traded and for most countries their market price data has only been reliable since end 2007. The data on sovereign yield spreads and CDS are also prone to political interference; for example, in the recent European sovereign debt crisis, the authorities banned naked/uncovered purchases of sovereign CDS based on EA countries (International Monetary Fund (2013)). For some countries, the ECB provided price support to sovereign bonds in both primary and secondary markets. This aggravates the issue of liquidity and relevance. Thus, CDS and yield spreads are no longer indicative of what investors think about the credit risk but reflect more a mix of default risk expectations and forecasts of rescue measures. This is yet another instance of Goodhart's Law - a variable that becomes a policy target soon loses its reliability as an objective indicator' (Goodhart (1975a), Goodhart (1975b)). Studies examining the determinants of credit rating also suggest the pro-cyclical nature of credit ratings and their inadequate treatment of the domestic fiscal stance (see Soudis (2016)).

Moreover, since most sovereign debt contracts offer no explicit seniority to particular groups of creditors, the sovereign credit risk measures do not differentiate between the bond holdings of multilateral creditors (like the ECB, IMF, ESM, etc.) to those of a private investor. However, in a survey analysis, Steinkamp and Westermann (2014) showed that almost $90 \%$ of the market participants expect at least one of the multilateral' creditors holding to be senior to private investors. These authors also document the reactions of rating agencies, which justified their downgrades explicitly pointing to the seniority issue. The Greek debt restructuring in 2012 also validated this differentiation in which we observe asymmetrical losses were observed across creditors and across debt instruments based on the seniority of creditors and maturity of different bonds (see, e.g., Zettelmeyer et al. (2013)). This trancheing of the sovereign default risk for creditors based on their seniority pushes the credit risk measures gradually towards the riskiness of junior claim holders.

Against this background, this paper presents a new framework to measure and analyse sovereign credit risk in currency union countries using the structural model of Merton (1974), which was extended towards sovereign credit risk by Gapen et al. (2005). We exploit the observed price and market behaviour in sovereign debt restructuring and build a credit risk indicator that incorporates this in our credit risk measurement. Therefore, the main purpose of this paper, is to show how modern contingent claims analysis (CCA) can be modified and used to measure and analyse risk stemming from the public sector balance sheet, allowing the calculation of an indicator that measures sovereigns' distance-to-default (DtD). Estimating risk using an approach of this kind has a long tradition in modern financial theory but has only been applied to gauge sovereign risk in the case of emerging countries.

Why CCA? Taking stock of the rapid advances in the growing literature on measuring sovereign credit risk, our own assessment is that CCA offers the best possibility for incorporating the seniority structure of creditors in an already existing theoretical model. It is a theory grounded, market-based approach to analyse and measure the credit risk of a legal entity (firm or sovereign). The basic approach rests on the generalization of the option pricing theory pioneered by Black and Scholes (1973) and Merton (1974). The principle un- 
derlying the model is that if the liabilities of a legal entity have different priority (e.g., senior and junior), then the junior claims can be modelled as a call option on the asset value of the legal entity with senior claims as the strike price. The idea also gives legitimacy to current bankruptcy proceedings, in which the bankrupt entity formally surrenders its assets to its creditors and sale proceedings are divided among creditors based on the priority structure of liabilities.

CCA methodology is commonly called the "Merton Model." It was first adapted and utilized commercially by the KMV Corporation (Crosbie and Bohn (2003)) and is now firmly established as the theoretical basis for several applied models that are used to measure and evaluate credit risk for firms and emerging market sovereigns (see Bharath and Shumway (2008), European Central Bank (2012), Saldias (2013), Gray and Jobst (2010), Gray et al. (2010), Gray and Malone (2008), Gray et al. (2007), Gray and Walsh (2008), Harada and Ito (2008) and Harada et al. (2010)).

This paper is an extension of the existing CCA - based methodology for countries which are members of a monetary union (EA) which lacks the ability to inflate away its debt in a distressed situation. To the best of our knowledge, this is the first paper to examine the application of CCA - based methodology for monetary union countries, and describes in detail a novel framework for measuring the sovereign credit risk. Based on creditors' seniority, we define a unique priority structure of debt holders and incorporate it into the theoretical model to calculate the credit risk for peripheral EA countries. Furthermore, this paper also contributes to the existing literature by comparing the proposed indicator with the traditional vulnerability indicators.

Our results suggest that the addition of this idiosyncratic component for individual sovereigns which is primarily linked to the sectoral distribution of their creditors, especially the debt held by multilateral creditors increases the information content of the sovereign credit risk measure. As most sovereign debt contracts offer no explicit seniority to a particular group of creditors, the existing sovereign risk measures increasingly reflect the risk for the junior claim holders and create a bias in all market-based credit risk measures. Once corrected, the new risk indicators are less correlated across countries, than the traditional market-based credit risk indicators (i.e., CDS spreads, sovereign yield spreads and credit ratings). Even though they share a highly correlated underlying factor linked to global risk and uncertainty, their weight diminishes in times of crisis. They also show better predictive ability and causal linkages with other sovereign risk measures.

The paper is organized as follows. Section 2 provides a review of the empirical literature on the main drivers of the traditional sovereign credit risk indicators. In Section 3, we give a conceptual overview of the Merton model, with an explanation of the basic features of the quantitative model. This is followed by a discussion of the challenges facing the direct application of this model to the EA setting. We then show how this model can be modified and used to quantify the credit risk for EA countries. Section 5 enumerates the databases used and the practical considerations in sovereign credit risk calculations. In section 6 , we illustrate the application of our modified model to the actual data of EA countries, namely Greece, Ireland, Italy, Portugal, and Spain for the period 2000-2016. Section 7 explores in details the actual and potential implications of this framework for sovereign credit risk 
management. Finally, Section 8 offers some concluding remarks.

\section{Literature review on traditional sovereign credit risk measures}

The sovereign debt crisis in Europe, which began in late 2009, revived the literature on EA sovereign yield spread drivers and has attributed increasing importance to uncertainty and variables reflecting investment confidence and perceptions for the upcoming economic activity (see, among others, Georgoutsos and Migiakis (2013) or Beirne and Fratzscher (2013)). Many authors have also stressed the importance of other fundamental variables beyond the country's fiscal position to explain yield spread behaviour after the outbreak of the crisis (Allen et al. (2011) or Acharya and Schnabl (2014), to name a few). In particular, Gomez-Puig et al. (2014) empirically investigate the determinants of EA sovereign bond yield spreads with respect to the German bund from January 1999 to December 2012, using panel data techniques and examining the role of a very exhaustive set of potential drivers. Their results stress that the rise in sovereign risk during the crisis can only partially be explained by the evolution of local macroeconomic variables. Specifically, they find that the relevance of the variables that measure global market sentiment increased during the crisis, especially in peripheral EA countries. These results have been corroborated by many other authors. Aristei (2014), who also investigate sovereign spreads drivers in ten EA countries during the 2000-2012 period, show that proxies of consumer and market sentiment and expectations strongly affect spreads behaviour, especially during the crisis. Silvapulle et al. (2016), whose analysis focuses on peripheral EA countries during the 1999-2013 period, find that market sentiment variables (the stock returns or the VIX index, among them) had a significant impact on bond yield spreads in the crisis period. Boysen-Hogrefe (2017) argue that, since the announcement of the outright monetary transactions program (OMT), the debt-to-GDP ratio has become less relevant as a determinant for government bond spreads, while financial markets have become more concerned about the willingness and capability to cooperate with the institutions that conduct the adjustment programs. Finally, the analysis of Paniagua et al. (2017) also provides empirical evidence suggesting that not only fiscal indebtedness, but also a shift in global risk aversion and the worsening of other fundamentals, have played a significant role in explaining the evolution of long term spreads in peripheral EA countries.

The nature of sovereign credit risk using CDS data has been studied by Longstaff et al. (2011) for a sample of 26 developed and emerging countries during the 2000-2010 period by conducting a principal component analysis of the changes in sovereign CDS. Their results show that sovereign credit risk measured by CDS spreads tends present much higher correlations across countries than equity index returns for the same countries, due to the dependence of sovereign credit spreads on a common set of global market factors. Specifically, they find that a single principal component accounts for $64 \%$ of the variation in sovereign credit spreads. Badaoui et al. (2013) also try to isolate default risk from the sovereign risk premium in a sample of emerging market countries during the period 2005-2010; their decomposition exercise puts forward the idea that the increase in CDS spreads observed during the crisis period was mainly due to a surge in liquidity rather than to an increase in the default intensity. Broto and Perez-Quiros (2015), who analyse the sovereign CDS spreads of 
ten OECD countries with a dynamic factor model, conclude that although the CDS premium contains highly relevant information on sovereign risk, it must be previously corrected by the portion of the premium related to overall risk aversion and qualified by the contagion effects that may be present in it. Blommestein and Qia (2016) also find that contagion from the global financial market is an important factor affecting the pricing of CDS spreads in their sample of peripheral EA countries. Another interesting result is that, in contrast to previous studies which focused on pre-crisis periods, Blommestein and Qia (2016) find that domestic and economic financial developments have little impact on sovereign credit risk in Greece, Ireland, Portugal and Spain during the crisis. The causality is in fact the other way round: sovereign credit risk significantly affects domestic economic and financial developments in crisis times. Fabozzi and Tsu (2016) introduce a novel technique of factor decomposition (independent component analysis) to investigate the behaviour of EA sovereign CDS spreads during the debt crisis. Their results identify three important factors: the risk associated with the peripheral countries, the global risk, and the EA common risk. They also show how the main source of risk changes over time: in 2009, it was the global factor, in 2010 the peripheral factor, and finally in 2012 the EA common factor. Finally, Aizenman et al. (2013) and Rubia et al. (2016) agree that if sovereign CDS spreads are wrongly assumed to solely reflect default risk, the severity of the underlying market conditions may be substantially overestimated, particularly during periods of distress. Specifically, according to Rubia et al. (2016) the case of peripheral EA countries in the midst of the debt crisis might illustrate this point accurately, since sovereign CDS contracts were traded at prices that were too high to reflect solely the credit default risk premium.

Finally, credit rating agencies (CRA) have played a prominent role in the recent financial crisis. They assign a credit rating to sovereign and private sector borrowers which indicates the probability of their failing to fulfil their obligations in their debt issues. Specifically, understanding the dynamics of sovereign credit ratings is highly relevant given their implications for capital flows and their strong link with private ratings. Despite their importance, the CRA do not provide enough detail about the ratings' determinants or their rating procedures (Mora (2006)), in spite of some recent regulatory initiatives to improve transparency. Some empirical literature has examined the main determinants of ratings and most papers state that CRA do not adjust adequately to domestic indicators. For instance, Soudis (2016), who applies the extreme bounds analysis technique to approximately 30 factors proposed by the literature as determinants of the ratings, finds that variables such as rule of law, openness to economic flows, central bank independence, and market-friendly policies are more robustly correlated with the ratings than foreign reserves, fiscal deficit, sovereign bond yields, and economic growth. Likewise, Boumparis and Panagiotidis (2017), who examine ratings determinants for EA countries during the 2002-2015 period, find that economic policy uncertainty impacts negatively on credit rating, especially in the lower rated countries. In other words, the creditworthiness of low rated countries takes a much bigger 'hit' than that of high rated countries when uncertainty rises. Other authors conclude that there is a certain amount of lag in the agencies' response to domestic variables and the debate revolves around the procyclical or sticky nature of ratings. Some authors (Ferri et al. (1999) and Monfort (2000), among them) point out that ratings are procyclical, meaning that in 
downgrade phases CRA are oversensitive to fundamentals and this, in turn, contributes to exacerbating the existing crisis. Other authors, such as Mora (2006) state that ratings are sticky rather than procyclical (they are adjusted only when there is a sufficiently large divergence between predicted and assigned ratings). More recently, Broto and Molina (2016) present mixed conclusions, as the reaction of the agency to macroeconomic developments differs during downgrade and upgrade periods: downgrade phases would have a procyclical nature, with a certain amount of lag, whereas upgrade periods would tend to be sticky.

All in all, the existing empirical literature on the determinants of traditional sovereign credit risk measures (bond yield spreads, CDS and ratings) suggests that those indicators are driven by factors other than the fiscal position, especially in times of crisis. In other words, since they are market based indicators and do not solely reflect default risk, they may substantially overestimate the difficulties of governments in repaying their debt, especially in periods of distress. In this context, the sovereign DtD indicator proposed in this paper - which includes both accounting metrics and market-based measures - aims to isolate sovereign credit risk by using information from the public sector balance sheets to build it up.

\section{An overview of CCA}

Consider a legal entity (firm, bank or sovereign) whose capital structure consists of only two types of liabilities (both due at time $T$ ), differing only in terms of their seniority. ${ }^{3}$ For simplicity let's call them - senior and junior claims. Also, assume that the entity promises to pay a fixed amount $S$ to the senior creditors, and the remainder to the junior creditors. Therefore at maturity $T$, if the total value of assets of the entity is $A$, then the pay-off for the senior claim holder ' $P_{S}$ ' will be, $P_{S}=\min \{S, A\}$, while the pay-off for the junior claim holder ' $P_{J}$ ' will be $P_{J}=\max \{A-S, 0\}$.

This pay-off for the junior creditors is analogically similar to the pay-off for the buyer of a typical call option. For a given strike price $K$, the pay-off for the buyer of the call option depends on the firm's equity price $E$, and is given by $P_{C}=\max \{E-K, 0\}$, where $E$ is the firm's equity value at the maturity of the option. CCA exploits this analogy and the fundamental relationships between the value of an entity's assets and the dependent contingent claim (the call option). The junior claims are modelled as an implicit call option on the value of the entity's assets while considering the senior claims as the strike price. So if the entity's future senior claims are known and its junior claims are tradable in the marketplace, then CCA uses this information to derive the value of the entity's asset $(A)$ and asset volatility $\left(\sigma_{A}\right)$. The methodology is well established in the literature (see Black and Scholes (1973), Merton (1974, 1977), Gray et al. (2007), European Central Bank (2012), Saldias (2013), Gray and Jobst (2010), Gray et al. (2010), Gray and Malone (2008), Gray and Walsh (2008)). For a detailed presentation, please see Appendix A.

\footnotetext{
${ }^{3}$ By seniority, we mean that the senior creditors are the first to recover their money in case of insolvency while the junior creditor receives only what is left once the senior creditors have been paid.
} 
Distress occurs when the market value of an entity's assets declines relative to its contractual obligations ( $S$ in this case) or when asset volatility increases such that the value of assets becomes highly uncertain and the probability of the value falling below the contractual obligation increases. Default occurs when the value of an entity's assets falls below its contractual obligation known as the 'default point' in the literature. One way to define this concept is through the calculation of "Distance-to-default $(D t D)$ " which is defined as the number of standard deviation the entity's asset value is away from its contractual obligation.

$$
\text { Distance }- \text { to }- \text { default }(D t D(t))=\frac{A(t)-S}{A(t) \sigma_{A}(t)}
$$

An alternate way is to define a risk-adjusted Distance-to-default $\left(D t D^{R A}\right)$ as the distance between the expected future value of the entity's asset and the default point.

$$
D t D^{R A}(t)=\frac{\log \left(\frac{A(t)}{S}\right)+\left(r-0.5 \sigma_{A}^{2}\right)(T-t)}{\sigma_{A} \sqrt{T-t}}
$$

Here $r$ denotes the risk-free rate. If substituted in the normal cumulative density function, we can calculate the probability of default $(P D(t))$ as,

$$
P D(t)=P[A(t) \leq D]=\Phi\left(-D t D^{R A}(t)\right)
$$

Conceptually there is not much difference between these risk indicators. The level and variation vary numerically but the change always points in the same direction for the entity's health. Given this, from now on, we will document all our analysis based on the $D t D$ calculated using equation (1).

\subsection{Application of CCA balance-sheet approach for firms}

A firm is an economic organization in which a team of people coordinates their skills in order to produce goods and services. The typical liability structure of a firm has two basic components. The first is debt contracts to borrow money for a fixed period of time in the form of loans and bonds, and their holders (creditors) have to be repaid irrespective of whether the firm is successful. The second is equity contracts to borrow money with no promise of repayment. Repayment is conditional on whether the firm succeeds. If it is successful, the equity holders (shareholders) receive a part of the profit.

A formal insolvency regime for corporate debt restructuring sets out, in general terms, how these different types of claimants on a distressed firm will be treated in a restructuring process and establishes the order of payment in the event of outright liquidation. These rules tell a firm's creditors/shareholders where their claims stand in the pecking order. As the contracts suggest, the bankruptcy laws consider debt holders as senior claimants compared to shareholders. Debt gets paid first, and whatever remains is paid to the shareholders. As shareholder claims are junior compared to creditors, the value of the firm's equity can be modelled as a call option on its assets in which the outstanding debt is considered as the strike price. If the firm is publicly traded then CCA can use their debt and equity price data to derive a set of credit risk indicators. 
However, in practice, the application of CCA for a firm is quite challenging. A firm's liability structure usually involves debt and equities of many different kinds with different priorities. The levels and amounts of contractual liabilities due are relatively easy to determine from the balance sheet information but they are spread across time, based on the debt maturity profile. This makes defining the exact distress barrier (the strike price in the case of a call option) extremely difficult. Based on the time horizon of interest, different distress barriers can be defined which can be combinations of the contractual obligations which are due in the coming years. An extensive survey of the literature suggests that for corporate credit risk measurement, the distress barrier is calculated as the sum of short-term debt, interest payments due within a year, and $50 \%$ of the long-term debt (see Singh et al. (2015)).

Evidence from the universe of corporate defaults also indicates that the market value of a firm's assets can sometimes trade below its contractual liabilities for a significant period of time. This is most often the case when the majority of liabilities are long-term, allowing the firm to continue servicing debt payments while undertaking steps to improve its financial health. Another possible explanation can be investors' faith in the firm's long-term sustainability and recovery. Therefore, in estimating corporate default risk, the value of assets that triggers a distress is assumed to lie somewhere in between the book value of total liabilities and short-term liabilities.

\subsection{Application of CCA balance-sheet approach for emerging market sovereigns}

In order to apply the CCA for emerging countries, we must first understand the liability structure of the emerging market sovereigns. For the systematic presentation, Table 1 shows a simplified version of the sovereign accounting balance sheet. ${ }^{4}$ On the asset side, Foreign reserves measure the net international reserves of the public sector. Net fiscal asset is the present value of the primary fiscal surplus over time (the present value of fiscal surplus minus interest payments) while Other public assets include the government's equity in public enterprises.

On the liability side, Base money is a liability of the monetary authorities and consists of the total currency in circulation and bank reserves (required bank reserves, excess reserves, vault cash). Local-currency debt of the government and monetary authorities are the total government-issued debt held outside the monetary authorities and the government. Foreigncurrency debt is the part of the sovereign debt which is denominated in foreign currency. It is usually held by foreigners. Guarantees compose the implicit or explicit financial guarantees provided by the government to banks, financial institutions or contingent pension/social obligations.

CCA ignores the asset side of the balance sheet and works only with the liability side. It circumvents the problems of assessing the market value of all sovereign assets by estimating sovereign asset value and volatility indirectly with information on observable values of the liability side of the balance sheet. ${ }^{5}$ Since liabilities are claims on current and future assets, this approach yields an 'implied' estimate for a sovereign's assets - value and volatility. The

\footnotetext{
${ }^{4}$ This section borrows heavily from Gray et al. (2007).

${ }^{5}$ The problem can also be approached from the asset side of the sovereign balance sheet. Foreign reserves
} 
Table 1: Accounting balance sheet for the sovereign (combined government and monetary authorities)

\begin{tabular}{l|l} 
Assets & \multicolumn{1}{l}{ Liabilities } \\
\hline Foreign reserves & Base money \\
Net fiscal assets & Local currency debt \\
Other public assets & Foreign currency debt \\
& Guarantee \\
\hline
\end{tabular}

collective view of many market participants is incorporated in the observable market prices of liabilities, and the change in the market price of these liabilities determines the volatility. ${ }^{6}$

The sovereign balance sheet has two liabilities (foreign and local currency debt) whose value can be derived from sovereign assets and can be valued as contingent claims. However, seniority is not defined by legal status, as in the case of corporate liabilities, and must be inferred from observed government behaviour The emerging countries debt default and restructuring experiences of the last four decades suggest that governments often make strenuous efforts to remain current on their foreign-currency debt. These efforts effectively make foreign currency debt senior to domestic currency debt when governments show flexibility in issuing, repurchasing, and restructuring (see Eichengreen et al. (2002) and Sims (1999)). ${ }^{7}$

Thus, sovereign local currency debt can be modelled as an implicit call option on a sovereign's asset value. The market value of local currency debt and its price volatility is

can be directly measured. For the Net fiscal assets, a reasonable value can be estimated by discounting all future expected cash flow (such as primary surplus) with an appropriate discount rate. Other public assets value can be determined from the observed market prices of all or part of the assets. This can be a market price quote, direct observation, bid-ask quote or other similar direct measures. In the case of illiquid securities for which no direct market price is available, a comparable or adjustable comparable security can be used as a proxy. Different expected future scenarios can then be generated to gauge the individual asset volatility (a procedure very similar to Debt Sustainability Analysis used by World Bank and IMF). The sovereign asset volatility can then be computed by aggregating the volatility of the individual assets using a weighting function.

The method looks straightforward but in fact is very difficult to apply. The tradable financial assets have direct or comparable observable market prices, but the implicit assets are extremely difficult to measure as this requires projecting the future cash flows, deciding the appropriate discount rate, and determining all the relevant components that underlie the cash flow projections for tangible and intangible items included in the asset value estimation. For example, determining the present value of the net fiscal asset requires estimates of future economic performance, a political commitment to a variety of programs including social security and other entitlement programs, and the use of an appropriate discount rate. Estimates for the value of other assets like the value of the public sector monopoly on money issuance run into similar problems. Furthermore, it is unclear how asset volatility should be best measured under this method.

${ }^{6}$ This approach implicitly assumes that market participants' views on prices incorporate forward-looking information about a sovereign's future economic prospects. This does not imply that the market is always right about its assessment of sovereign risk, but that it reflects the best available collective forecast of the expectations of market participants.

${ }^{7}$ Note that the underlying reason for this flexibility is the unlimited capacity of governments to print their own currency. 
then used to derive the implied market value and volatility of sovereign assets. While the promised payments, or distress barrier, are known with a fair degree of certainty over a time horizon based on the maturity profile of foreign currency debt, the literature defines the "distress barrier" as the present value of the promised payments on foreign-currency debt (see Gray et al. (2007)). Sovereign distress occurs when the sovereign assets are insufficient to cover the promised payments on the foreign-currency debt.

Note that the probability of sovereign distress is higher when a bigger fraction of debt is denominated in a foreign currency, or when most of the foreign currency liabilities are shortterm (rollover risk is high). Sovereigns can also sometimes trade below their contractual liabilities for a significant period of time if most of the liabilities are long-term, if most of the debt is denominated in the domestic currency or if the expected future fiscal position looks bright (higher implicit asset value).

\section{The modified approach: Application to EA countries}

\subsection{Why is there a need for modification?}

The most prominent feature of the EA is that, unlike emerging countries or other developed economies (e.g., US, UK, and Japan), individual EA countries are part of a monetary union. As part of the union, they do not have the possibility to inflate/dilute local currency debt in a distress situation before defaulting on foreign currency debt (for a detailed discussion, see De Grauwe (2012), Cochrane (2005) and Kopf (2012)). This effectively makes all EA sovereign debt 'foreign currency' debt, since their own central banks cannot print the currency in which their debt is denominated. Thus a case cannot be made that foreign currency debt holders are senior to local currency debt holders.

Also under the current institutional arrangement in the EA, the assets and liabilities of the monetary authority (the ECB) are independent of the sovereigns. In a practical sense, the monetary authority is just another lender to the sovereigns. The standard government view that credit from monetary authorities is the most junior obligation breaks down, and failing to honour this commitment can have serious consequences. This also exposes EA governments to the bouts of fear and distrust in the ECB's function as the lender of last resort. These fears can trigger a liquidity crisis, which can easily turn into a solvency crisis; higher interest rates and worsening debt dynamics can be self-fulfilling and sovereigns can effectively end up in default.

\subsection{Discussion on the seniority of EA sovereigns' liabilities}

The loss of control over domestic currency for EA countries, however, does not place all the creditors of an EA sovereign on a par with each other. To assess the seniority status of different actors and their precise place in the pecking order, we study the central episode of the European debt crisis - the restructuring and near-elimination of Greece's sovereign bonds held by private investors, comprising a face value of more than $100 \%$ of Greek GDP in March/April 2012 - together with the debt restructuring experience of multitude of emerging countries (see Roubini and Setser (2004)). Generally, government bonds come with a pari passu clause. However, the history of default and restructuring experiences in the context 
of sovereign lending makes it unclear what pari passu really means (see Weidemaier et al. (2013)).

There is surprisingly little de jure evidence that multilateral lenders are indeed senior to other creditors. It is primarily a convention and follows from the idea that, in future crises, this lender of last resort may be needed again in order to borrow further resources. ${ }^{8}$ For instance, the IMF, which has proven its seniority in the financial crises of the past decades, is de jure not senior - it awards its credit lines without any corresponding clauses in its contracts or institutional by-laws. Nevertheless, its seniority is widely accepted and has never been challenged in the course of the financial crisis, by any of the creditors. Bilateral official creditors have also respected the IMF's' privilege position. Indeed, the historical willingness of bilateral creditors to restructure their claims in order to ensure payment to the IMF has been central to the idea of the fund's preferential status. Even during the Greek debt restructuring, the most favourable treatment achieved by other institutional lenders were on a par with the treatment of the IMF. This makes the IMF de facto the most clearly senior lender of all (see Martha (1990), Steinkamp and Westermann (2014) and Roubini and Setser (2004)).

Other multilateral lending facilities like the first Greek loan facility, the temporary rescue fund (EFSF), the permanent rescue fund (ESM) and the Target2 balances are de jure not senior, although they constitute multilateral claims of institutions - the Eurogroup or the Eurosystem of Central Banks - which are widely accepted as preferred creditors. A sovereign's desire to maintain its future access to emergency financing and a good working relationship with the other governments that provide this is a powerful incentive to follow the convention of paying multilateral creditors even if it defaults on its other debts. Sometimes the lending clauses explicitly give them preferred creditor status, junior only to the IMF loan. Target2 balances already enforced their senior status in the case of the Greek private sector involvement (PSI) in 2012, sanctioning this market belief (for details, refer to Sinn and Wollmershäuser (2012) and Whelan (2013)).

The most challenging task is to classify the holdings of the ECB. The ECB became an important creditor of countries in crisis via its Securities Markets Programme (SMP), collateralized lending to financial institutions and, later, the Outright Monetary Transactions (OMT) in order to stabilize sovereign bond yields in secondary markets. As all government bonds bought in the open (secondary) market contain the same legal clauses, it became unclear how these bonds would be treated in case of restructuring. In the case of OMT, the ECB explicitly acknowledged that it accepts the same priority as other private creditors in accordance with the terms of those bonds. However, accepting pari passu treatment did not mean that the ECB was open to participating in voluntary debt restructuring, such as the Greek PSI in February/March 2012. The Greek debt restructuring proposal excluded the bond holdings of the ECB (the single largest holder by far, with 42.7 billion euros $(16.3 \%)$ of debt holding), other national central banks (5\% of the total) and the European Investment Bank (EIB) (for further details, refer to Zettelmeyer et al. (2013) and Steinkamp

\footnotetext{
${ }^{8}$ Kletzer and Wright (2000) show in a formal analysis that this reason is actually sufficient and that no external enforcement is required.
} 
and Westermann (2014)). So even if de jure the preferred creditor status of multilateral lenders is often ambiguous, their seniority is widely accepted by market participants.

Another interesting group of creditors is the domestic deposit-taking corporations (the banks). Markets believe that governments implicitly or explicitly undertake to honour the liabilities of too-important-to-fail banks. ${ }^{9}$ In many cases, we can think of these guarantees to too-important-to-fail banks as senior claims. The reason for this is that a sovereign's creditworthiness depends heavily on the creditworthiness of its domestic banks. A deterioration in the creditworthiness of banks, as perceived by the market, can drastically increase the sovereign's contingent liabilities. This may cause a the government's own creditworthiness to deteriorate. Since the asset side of the bank's balance sheet typically consists of substantial holdings of domestic government debts, a deterioration in the government's creditworthiness can cause huge losses in its banks' portfolios. Sovereign fiscal strains can also impact banks' funding conditions since government securities are typically used as collateral to obtain short-term funding in debt markets. ${ }^{10}$ Thus a self-fulfilling vicious loop develops in which deterioration in banks' health can increase the sovereign's contingent liability and fiscal strain which in turn has a negative impact on the banks' health.

Banks are also locked into a long-term relationship with the government. During times of crisis, domestic banks in fiscally stressed countries increase their holdings of domestic sovereign debt considerably relative to foreign banks. This effect is stronger for state-owned banks and for banks with low initial holdings of domestic sovereign debt. This practice complies with the moral suasion argument ${ }^{11}$ where banks choose to respond to pressure from their government on the understanding that current favours will be reciprocated in the future (for the presentation of the idea, refer to Horvitz and Ward (1987). Ongena et al. (2016) provide evidence of this behaviour during the European sovereign debt crisis.). This entails a natural collusion between two parties that have an equal interest, and so governments have an incentive to bail-out certain creditors more than others. Further uses of the bailout funds also indicate the priority banks receive over any other credit institution.

In summary, past experiences, survey responses and credit rating agencies' decisions have

\footnotetext{
${ }^{9}$ Grande et al. (2013) show that these guarantees help reduce risk premium on banks' liabilities and that their effect is proportional to the sovereign's creditworthiness. Implicit guarantees are harder to measure, but Angelini et al. (2011) and Schich and Lindh (2012) provide suggestive evidence that they may be among the reasons why on average large banks borrow at a discount.

${ }^{10}$ For example, in repo markets, a fall in the price of the sovereign bond can trigger margin calls or increase the haircut requirements, thus reducing the liquidity that can be obtained via a given nominal amount of sovereign paper. In an extreme scenario, a sovereign's rating downgrade below investment grade status disqualify it as collateral in funding operations, or as investments suitable for certain categories of investors such as pension and insurance funds.

Sovereign ratings also represent a ceiling for the ratings assigned to all other domestic borrowers. Increasing sovereign stress can lead to a ratings downgrade for a sovereign as well as its domestic banks, which in turn will increase the funding cost for banks.

${ }^{11}$ The term moral suasion originally refers to an appeal to 'morality' or 'patriotic duty' to induce behaviour by the persuaded agency that is not necessary profit-maximizing for it. This appeal can be combined with a threat of a more repressive regime, as in the case of banking - intensified supervision, a revocation of banking license, or limited access to central bank funding (Horvitz and Ward (1987)).
} 
all suggested that a certain group of creditors are de facto senior to other market creditors (preferred creditor status), even if this is not formalized de jure. The large increase in the share of sovereign debt holding by these senior de facto creditors in the peripheral EA countries total debt outstanding and its observed co-movement with the interest rate spreads (refer to Figure 4 in Steinkamp and Westermann (2014)) makes the question addressed in this paper extremely timely and policy relevant. As a result, we focus here on the de facto rather than de jure classification.

\subsection{Classification of creditors according to their place of residence and their institutional characteristics}

We start our analysis here with the classification of different sovereign creditors and propose a hierarchy structure based on the institutional classification of creditors. We classify all creditors according to their place of residence and their institutional characteristics. We define the institutional unit as an economic entity that is capable, in its own right, of owning assets, incurring liabilities, and engaging in economic activities and in transactions with other entities. We follow the guidelines established by the World Bank (WB) and the International Monetary Fund (IMF) in bringing together detailed public sector debt data of high-income countries (Quarterly Public Sector Debt Statistics (QPSD)). Specifically, the guidelines classify creditors into two broad categories: domestic and external.

Domestic creditors are re-classified further into the following five categories: (a) Domestic central bank; (b) Deposit-taking corporations except the central bank, comprising all resident public deposit-taking corporations, except the central bank, that are controlled by general government units or other public corporations; (c) Other financial corporations consisting of all resident financial corporations, except public deposit-taking corporations, controlled by general government units or other public corporations; (d) Non-financial corporations, i.e., corporations whose principal activity is the production of market goods or nonfinancial services $^{12}$; and (e) Households and non-profit institutions serving households. The external creditors are classified into: (a) Multilateral creditors - the ECB, EFSF/ESM, IMF, EIB, etc.; (2) Other national central banks within the EU; (c) Other non-resident financial corporations; and (d) Other non-residents.

\subsection{Application to EA}

Based on the discussion in the previous section, we define the priority structure of sovereign debt based on creditors' location and institutional classification, as shown in Table 2 (in decreasing order of priority). ${ }^{13}$

\footnotetext{
${ }^{12}$ All resident non-financial corporations controlled by general government units or public corporations that are part of the public non-financial corporations subsector.

${ }^{13}$ Another way to classify the priority structure of sovereign liabilities could be based on the laws under which the contractual agreement is signed. Debt agreements signed under foreign jurisdiction would have a higher priority than debt agreements signed under domestic law, as governments during the time of crisis can change the terms of the agreement by a legislative fiat. But due to limited data accessibility, we prefer not to use this classification.
} 
Table 2: Priority structure of sovereign liabilities

\section{Senior claims}

External creditor: Multilateral creditors outside the EU - the IMF, World Bank (EB), etc.

External creditor: Other multilateral creditors - the ECB, EFSF/ESM, EIB (the

European Investment Bank), etc.

External creditor: Other national central banks within the EU

Domestic creditor: Deposit-taking corporation

\section{Junior claims}

Domestic creditor: Domestic central bank

Domestic creditor: Other financial corporations

Domestic creditor: Non-financial corporations

Domestic creditor: Households and non-profit institutions serving households

External creditor: Financial corporations not elsewhere classified

External creditor: Other non-residents

\section{Data and methodology}

\subsection{Data description}

In this subsection, we enumerate the datasets used in building our sovereign distance-todefault (DtD) - an alternative indicator of sovereign credit risk.

1. Risk-free interest rate: We consider the 10-year benchmark German bund yields as the risk-free rate (Source: Bloomberg). ${ }^{14}$

2. Market value of sovereign debt: We use the Quarterly Public Sector Debt Statistics (QPSD) database, developed jointly by the WB and the IMF, which brings together detailed public sector debt data from selected developing and high-income countries. It disseminates public sector debt data at the quarterly frequency. A detailed user guide is available at the Task Force on Financial Statistics website. We use this database to download the following items: (1) Gross PSD, General Gov., All maturities, Debt Securities, Market value, National Currency; (2) Gross PSD, General Gov., All maturities, Debt securities, Nominal Value, National Currency; (3) Gross PSD, General Gov., Long-term, With payment due in more than one year, Debt securities, Nominal Value, National Currency; (4) Gross PSD, General Gov., Long-term, With payment due in one year or less, Debt securities, Nominal Value, National Currency; and (5) Gross PSD, General Gov., Short-term, Debt securities, Nominal Value, National Currency. Except for Greece, we have the market value of all outstanding debt securities

\footnotetext{
${ }^{14}$ Note that German bond yield is not always the lowest in EMU countries but during the time-frame of our study this was usually the case. We also used US government 10-year bond yields as risk-free rate and our results are robust to both these specifications.
} 
issued by the general government at the quarterly frequency. For the case of Greece, we use the nominal value. Figure 1 shows the evolution of gross general government debt as a percentage of GDP with sovereign DtD indices for individual countries.

[Figure 1 about here.]

3. Volatility of sovereign debt: We use data from the National Securities Market Commission (Comisión Nacional del Mercado de Valores (CNMV)), the agency responsible for the financial regulation of the securities markets in Spain. These are daily data on bond market volatility which is calculated as the annualized standard deviation of daily changes in 40-day sovereign bond prices. The quarterly value is then computed as the average of the last three months daily volatility. ${ }^{15}$ Figure 2 shows the evolution of bond price volatility with sovereign DtD indices for individual countries.

[Figure 2 about here.]

4. Sectoral sovereign bond holdings: We use the cross-country sectoral sovereign bond holdings data developed in Merler and Pisani-Ferry (2012) (available at Bruegel website) which gathers publicly available data provided by national authorities on a country-by-country basis for 12 countries (Belgium, Finland, France, Germany, Greece, Ireland, Italy, Netherlands, Portugal, Spain, UK and US). It provides a sectoral breakdown of sovereign debt holders based on a systematic and standardized re-classification of all creditors into five categories - banks, central banks, public institutions, other resident sectors and non-resident holders. For most of the countries the data go back to the late 1990s and are mostly recorded at the quarterly frequency. Figure 3 plots the evolution of non-resident holding of general government debt with sovereign DtD indices for individual countries.

[Figure 3 about here.]

\subsection{Methodology}

Based on our discussion in Section 4, we consider the priority structure of creditors shown in Table 2. However, the best available public data on sectoral classification of all creditors (the Bruegel dataset) classifies them in the following categories: (1) Resident banks; (2) Central bank; (3) Other public institutions; (4) Other residents; and (5) Non-residents. Notice that under this classification all external creditors are classified under the common heading of Non-resident debt holders. This limitation implies that we cannot separate out the debt holding of multilateral creditors with the rest of the non-resident holders, which

\footnotetext{
${ }^{15}$ To check the robustness of our results, we also calculate the volatility of sovereign debt using the 10-year benchmark sovereign bond yield daily data (Source: Bloomberg) and calculate the daily bond prices and daily returns. We use different specifications for coupon payments (zero coupon, $1 \%, 2 \%$ and $4 \%$ coupon rate at the half-yearly/annual frequency). The quarterly volatility is then calculated as the standard deviation of daily returns (in that quarter) and is then annualized. These different specifications only scale the level of $D t D$ and our main results are robust to all these specifications.
} 
restricts our understanding of the dynamic implications of the redistribution of sovereign debt among the external debt holders. Since we don't have exactly the same classification of creditors, we consider the value of the senior claims as the sum of the market value of all non-resident debt holdings (external) and resident bank holdings.

Our assumption here is that during the time of stress, the offloading/selling by other nonresident will be reflected in the market volatility. Also, the net buyers will be the multilateral creditors (like ECB, IMF, ESM etc.) or the domestic banks which will be reflected in the increased holding of the senior claimant (see Battistini et al. (2013), Acharya and Steffen (2015)). We also see that some of these debt buyers in the times of crisis are distressed debt hedge funds which were paid in full during the Greek debt restructuring (Zettelmeyer et al. (2013), Steinkamp and Westermann (2014)). So our assumption regarding the priority of non-resident debt holders is not far from reality.

We calculate a quarterly time series of the sovereign DtD for Greece, Ireland, Italy, Portugal and Spain. To this end, we use the market value of sovereign debt in the hands of junior creditors as the equity value. The value of junior claims is calculated by multiplying the market value of the sovereign's total debt as provided by the QPSD database together with the fraction of the total debt in the hands of junior creditors. The volatility of the sovereign bond price as provided by the CNMV is taken as the direct measure of the junior claim volatility. To calculate the default barrier, we use three other alternative specifications - (1) the sum of the general government's short-term debt and long-term debt where the payment is due in one year or less in nominal terms ${ }^{16}$; $(2)$ the sum of part one and $50 \%$ of the long-term debt where payment is due in more than one year in nominal terms; and (3) the sum of debt holdings to all external debt holders in nominal terms - to check the robustness of our results. ${ }^{17}$ Once the equity value, equity volatility and distress barriers are calculated, we use the procedure as documented in Appendix A to calculate the quarterly time series of sovereign DtD for individual EA countries.

\section{Stylized facts}

Our focus is on five EA member states that have experienced a sovereign debt crisis: Greece, Italy, Ireland, Spain, and Portugal. Table 3 provides summary information for the sovereign DtD indicators. The measurement does not include units of account as it represents the number of standard deviation the sovereign's asset value is away from its distress barrier. The average value of the sovereign DtDs ranges widely across countries: the lowest average is 10.78 for Portugal, and the highest is 19.01 for Italy. Both the standard deviations and the minimum-maximum values indicate that there is a significant time-series variation in the sovereign DtD indices. For example, in the cases of Greece and Ireland, it ranges from 0.92 to 42.09 and 3.76 to 35.22 respectively. We also observe consistently low DtD numbers for Portugal.

\footnotetext{
${ }^{16}$ Note that we are using nominal value in place of market value. This is because the QPSD statistics do not provide the market value of short and long-term debt for individual countries.

${ }^{17}$ Our results are robust to all these alternative specifications. However, to save space, we document results only on the basis of the first one.
} 
Table 3: Descriptive statistics for sovereign Distance-to-Default (DtD) indicators

$\begin{array}{rrrrrrrrr}\text { Mean } & \begin{array}{c}\text { Standard } \\ \text { Deviation }\end{array} & \text { Minimum } & \text { Median } & \text { Maximum } & \text { Skewness } & \text { Kurtosis } & \text { Standard } \\ & & & & & & & & \\ & & & & & & & & \\ 18.23 & 6.42 & 5.23 & 17.75 & 32.78 & 0.08 & -0.77 & 0.78 & 67 \\ 15.07 & 10.48 & 0.92 & 16.54 & 42.09 & 0.24 & -1.11 & 1.28 & 67 \\ 18.92 & 7.16 & 3.76 & 18.55 & 35.22 & -0.19 & -0.52 & 0.92 & 61 \\ 19.01 & 6.61 & 5.73 & 19.34 & 34.64 & -0.05 & -0.55 & 0.81 & 67 \\ 10.78 & 5.45 & 2.66 & 10.92 & 23.93 & 0.62 & -0.34 & 0.91 & 36\end{array}$

Notes: The table reports summary statistics for the quarterly sovereign DtD index for the period 2000Q1 to 2016Q3 (except for Portugal and Ireland). For Portugal, the series starts at 2007Q4, while for Ireland the series begins at 2001Q3.

\subsection{Commonalities within sovereign DtD indices}

To study the commonality in sovereign DtD indices, we first compute the correlations matrix of sovereign DtD levels. Since the time series of observations are not always of equal length, the correlation between each pair of countries is based on the periods for which the data overlap. The correlations matrix is shown in Table 4. All the correlations are positive and half of the pairwise correlations (Spain-Ireland, Spain-Italy, Spain-Portugal, GreeceItaly, and Greece-Portugal) are very large. In fact, half of all correlations are in excess of $80 \%$. The highest correlation 0.94 is observed between Italy and Spain. The average pairwise correlation is slightly above 0.75 and Spain shows the highest average pairwise correlation just above 0.86 .

Table 4: Correlations among sovereign DtD indicators

$$
\text { Spain Greece Ireland Italy Portugal }
$$

\begin{tabular}{llllll}
\hline Spain & 1.00 & 0.90 & 0.78 & 0.94 & 0.82 \\
Greece & 0.90 & 1.00 & 0.62 & 0.84 & 0.84 \\
Ireland & 0.78 & 0.62 & 1.00 & 0.65 & 0.44 \\
Italy & 0.94 & 0.84 & 0.65 & 1.00 & 0.70 \\
Portugal & 0.82 & 0.84 & 0.44 & 0.70 & 1.00 \\
& & & & & \\
\hline
\end{tabular}

Notes: This table reports Pearson correlations among the quarterly sovereign DtD indices for the 2000Q1 to 2016Q3 period. All correlations are statistically significant at $1 \%$ confidence level. 
To check whether the correlations have increased during the crisis period, ${ }^{18}$ we divide the sample period into two parts - (a) 2000 to 2007 as the pre-crisis period, and (b) 2008-2016 as the crisis period. We re-calculate the pairwise correlation for the 2000-2007 pre-crisis period as well as the 2008-2016 period encompassing the sovereign debt crisis (Table 5). We observe large differences in the average correlations. The average correlation is about $94 \%$ for the pre-crisis period, and it falls to $56 \%$ for the crisis period. We find the biggest drop in average correlation for Ireland - from 0.94 to 0.32 and a similar but less intense drop for Greece - from 0.94 to 0.50 . The largest drop is between the Ireland-Greece pair, where it fell to 0.06 from 0.95 pre-crisis. This provides suggestive evidence of an increase in idiosyncratic components in the sovereign credit risk measure. All correlations are still positive but, the magnitude of the pair-wise correlation has been reduced drastically for individual pairs.

Table 5: Correlations among individual sovereign Distance-to-Default (DtD) indicators

\begin{tabular}{|c|c|c|c|c|c|c|c|c|c|c|}
\hline & \multicolumn{5}{|c|}{ 2000-2007 } & \multicolumn{5}{|c|}{ 2008-2016 } \\
\hline & Spain & Greece & Ireland & Italy & Portugal & Spain & Greece & Ireland & Italy & Portugal \\
\hline Spain & 1.00 & 0.92 & 0.92 & 0.94 & - & 1.00 & 0.61 & 0.52 & 0.89 & 0.80 \\
\hline Greece & 0.92 & 1.00 & 0.95 & 0.94 & - & 0.61 & 1.00 & 0.06 & 0.55 & 0.82 \\
\hline Ireland & 0.92 & 0.95 & 1.00 & 0.96 & - & 0.52 & 0.06 & 1.00 & 0.27 & 0.41 \\
\hline Italy & 0.94 & 0.94 & 0.96 & 1.00 & - & 0.89 & 0.55 & 0.27 & 1.00 & 0.68 \\
\hline Portugal & - & - & - & - & - & 0.80 & 0.82 & 0.41 & 0.68 & 1.00 \\
\hline
\end{tabular}

Notes: The table reports Pearson correlations between the quarterly sovereign DtD indices for the 2000Q1 to 2016Q3 period. All correlations are statistically significant at 1\% confidence level. The pre-crisis period excludes Portugal because the sovereign DtD for this country is available only from 2007Q4 onwards.

\subsection{Commonalities and differences with regard to other sovereign risk measures}

In this section, we study the commonalities and differences among the various sovereign credit risk measures. In particular, we conduct the principal components analysis of the sovereign DtD and contrast the results with other credit risk measures. However, we need to be selective because a large number of credit risk indicators are available in the marketplace. We narrow our analysis to sovereign yield spreads, CDSs and the credit ratings.

To calculate yield spreads for individual countries, we use the Maastricht criterion bond yields (the long-term interest rates). These are the rates used as a convergence criterion for the EMU, based on the Maastricht Treaty. The series relates to interest rates for longterm government bonds denominated in national currencies. The data are based on central

\footnotetext{
${ }^{18}$ As discussed by Longstaff et al. (2011), Ang and Bekaert (2002), and others, there is a tendency for correlations in financial markets to increase during crisis episodes.
} 
government bond yields on the secondary market, gross of tax, with a residual maturity of around 10 years, collected from Eurostat. Yield spreads are calculated as the difference between the ten-year benchmark sovereign bond yield of each individual country and that of Germany. Figure 4 shows the country-wise evolution of sovereign DtD and yield spreads. As can be seen, the sovereign DtD and yield spreads mirror each other for all countries in our sample. However, in the cases of Greece and Ireland, the level of DtD remains at dangerously low levels even when the level of yield spreads suggests otherwise.

[Figure 4 about here.]

We use five-year benchmark sovereign CDS daily mid-quotes from Datastream as the second measure of the sovereign credit risk. These data are available from 2007Q4 until 2016Q3. Following previous studies, we focus on the 5-year maturity, as these contracts are regarded as the most liquid in the market. Figure 5 show the country-wise evolution of the sovereign DtD index together with the 5-year benchmark sovereign CDS spreads for peripheral EA countries. Except for Greece, the CDS spreads have fallen drastically for all countries, though it remains higher than its pre-crisis level. The sovereign DtD reflects the same trend but shows far higher variation than the CDS spreads. Among the reasons for this variation are the fluctuations in bond market volatility, which are more pronounced in the case of smaller countries.

[Figure 5 about here.]

Finally, for credit ratings, we follow Blanco (2001) and build a credit rating variable (RAT) averaging the ratings assigned to sovereign debt by Standard \& Poor's, Moody's and Fitch. Using data compiled from Bloomberg, 21 different categories are considered. The first category is made up of the highest-rated debts, while the twenty-first category includes the lowest-rated debts. Therefore, by construction, the higher the value of RAT, the worse the rating categories. Figure 6 shows the country-wise evolution of the sovereign DtD index together with the credit rating for each peripheral EA country. The plot suggests that credit ratings show less frequent and extreme movements compared with other sovereign risk measures. Sovereign DtD matches the trend of credit ratings, but shows far higher volatility.

[Figure 6 about here.]

Table 6 provides summary information for CDS, yield spreads and credit ratings which are selected here for comparison.

\subsubsection{Correlations among sovereign risk measures}

In this section, we compute the correlations between sovereign DtD and traditional measures of credit risk for individual peripheral EA countries. Since the time series of observations are not always of equal length for all indicators, we select the longest continuous period for which the data overlap. This period turns out to be 2008Q4 to 2016Q3. Table 7 
Table 6: Descriptive statistics for other comparable sovereign risk indicators

Standard

Mean Deviation Minimum Median Maximum Skewness Kurtosis Error N

\section{Part I: Five-year sovereign Credit Default Swap (CDS) spreads}

\begin{tabular}{|c|c|c|c|c|c|c|c|c|}
\hline Spain & 140.77 & 100.98 & 18.79 & 91.3 & 402.16 & 0.95 & -0.14 & 16.83 \\
\hline Greece & 8200.64 & 7102.17 & 20.32 & 13180.66 & 14904.36 & -0.15 & -1.98 & 1183.7 \\
\hline Ireland & 227.23 & 226.1 & 33.09 & 138.7 & 841.86 & 1.16 & 0.11 & 39.97 \\
\hline Italy & 148.36 & 100.2 & 19.58 & 108.91 & 415.01 & 1.22 & 0.63 & 16.7 \\
\hline Portugal & 318.58 & 313.06 & 28.99 & 215.7 & 1170.3 & 1.49 & 1.16 & 52.92 \\
\hline
\end{tabular}

Part II: Sovereign yield spreads

\begin{tabular}{|c|c|c|c|c|c|c|c|c|c|}
\hline Spain & 1.06 & 1.28 & 0.01 & 0.37 & 5.29 & 1.37 & 1.08 & 0.16 & 67 \\
\hline Greece & 4.53 & 5.87 & 0.15 & 0.87 & 26.52 & 1.52 & 2.03 & 0.72 & 67 \\
\hline Ireland & 1.38 & 2.01 & -0.04 & 0.39 & 8.54 & 1.81 & 2.44 & 0.25 & 67 \\
\hline Italy & 1.13 & 1.16 & 0.14 & 0.59 & 4.88 & 1.48 & 1.52 & 0.14 & 67 \\
\hline Portugal & 2.04 & 2.81 & 0 & 0.56 & 11.18 & 1.76 & 2.41 & 0.34 & 67 \\
\hline
\end{tabular}

Part III: Credit ratings

\begin{tabular}{lrrrrrrrrr} 
Spain & 3.64 & 3.34 & 1 & 1.67 & 9.67 & 0.91 & -1.04 & 0.41 & 67 \\
Greece & 10.01 & 5.44 & 5 & 6.00 & 19.33 & 0.61 & -1.50 & 0.66 & 67 \\
Ireland & 3.58 & 3.25 & 1 & 1.00 & 9.00 & 0.64 & -1.38 & 0.40 & 67 \\
Italy & 5.06 & 2.27 & 3 & 4.00 & 9.00 & 0.88 & -1.05 & 0.28 & 67 \\
Portugal & 6.47 & 4.57 & 3 & 3.33 & 15.00 & 0.84 & -1.02 & 0.56 & 67 \\
\hline
\end{tabular}

Notes: Part I of the table reports summary statistics for the quarterly average five-year sovereign CDS spreads for the period 2007Q4 to 2016Q3. CDS spreads are measured in basis points (Source: Bloomberg). Part II reports summary statistics for the quarterly sovereign yield spreads for the period 2001Q1 to 2016 Q3. The yield spreads are measured in percentage terms (Source: Eurostat). Part III of the table reports summary statistics for the quarterly average sovereign credit rating indicators for the 2000Q1 to 2016Q3 period. The rating is the average of sovereign credit rating available from S\&P's, Moody's and Fitch rating agencies (Source: Bloomberg). 
shows the correlation results for individual countries. As can be seen, most of the pairwise correlations are large and all of them are negative. In fact, they are all between -0.5 and -0.8. The average correlation for Ireland is the highest at -0.76 , while the lowest is for Greece at -0.62. The magnitude of the correlations is quite similar for CDS and yield spreads in almost all countries. These results suggest a strong pattern of commonality in sovereign risk measures, except for the credit rating excluding Greece. The low correlation between the DtD and the rating may be explained by the fact that our index probably captures information over and above the market-perceived credit worthiness of government bonds.

Table 7: Country-wise correlations among comparable sovereign risk indicators

\begin{tabular}{lccccc} 
& \multicolumn{5}{c}{ Sovereign DtD } \\
& Spain & Greece & Ireland & Italy & Portugal \\
\hline CDS spreads & -0.69 & -0.56 & -0.77 & -0.71 & -0.71 \\
Yield spreads & -0.68 & -0.68 & -0.75 & -0.71 & -0.75 \\
Credit rating & -0.19 & -0.78 & 0.18 & -0.33 & -0.44 \\
& & & & & \\
\hline
\end{tabular}

Notes: This table reports the Pearson correlations among the quarterly sovereign DtD with sovereign CDS and yield spreads for individual peripheral EA countries under study. The sample period is 2008Q4 to 2016Q3, the period for which we have the CDS, yields, ratings and sovereign DtD data for all peripheral EA countries. All correlations are statistically significant at $1 \%$ confidence level. The results are robust to other correlation measures.

\subsubsection{Principal component analysis}

In search of a common underlying factor, we now turn to principal component analysis. Table 8 reports summary results for the 2008Q4-2016Q3 period. ${ }^{19}$ For comparison, we also report the principal components for sovereign CDS, yield spreads and credit ratings. The results show that there is a strong commonality in the behaviour of all four indices, since the first two principal components explain roughly $90 \%$ of the variation for all risk measures. However, the explanatory power of the first principal component registers its lowest values in the case of the sovereign DtD $(67.17 \%)$, while the highest values correspond to the credit ratings at $87.91 \%$ followed by sovereign yield spreads at $83.30 \%$.

To explore this further, Figure 7 plots the weighting vectors for the first three principal components for sovereign DtD together with the other three risk measures. As shown, the first principal component consists of a roughly uniform weighting of 0.5 ( -0.5 in case of sovereign DtD) for all risk measures. We can think of it as a parallel shift factor driven by global risk and uncertainty as suggested by Longstaff et al. (2011). Also, the correlations

\footnotetext{
${ }^{19}$ This is the period for which sovereign $\mathrm{DtD}$ is available for the peripheral EA countries under study.
} 
Table 8: Principal component analysis result (2008Q4-2016Q3)

\begin{tabular}{|c|c|c|c|c|c|c|c|c|}
\hline Principal & $\begin{array}{l}\text { Percentage } \\
\text { Explained }\end{array}$ & Total & $\begin{array}{l}\text { Percentage } \\
\text { Explained }\end{array}$ & Total & $\begin{array}{l}\text { Percentage } \\
\text { Explained }\end{array}$ & Total & $\begin{array}{l}\text { Percentage } \\
\text { Explained }\end{array}$ & Total \\
\hline & \multicolumn{2}{|c|}{ Sovereign DtD } & \multicolumn{2}{|c|}{ CDS spreads } & \multicolumn{2}{|c|}{ Yield spreads } & \multicolumn{2}{|c|}{ Credit rating } \\
\hline First & 67.17 & 67.17 & 70.19 & 70.19 & 83.30 & 83.30 & 87.91 & 87.91 \\
\hline Second & 19.51 & 86.68 & 24.24 & 94.43 & 9.88 & 93.18 & 9.32 & 97.23 \\
\hline Thirc & 9.92 & 96.59 & 3.80 & 98.23 & 3.79 & 96.97 & 2.07 & 99.30 \\
\hline Fourth & 2.21 & 98.81 & 1.24 & 99.47 & 2.25 & 99.22 & 0.45 & 99.76 \\
\hline
\end{tabular}

Notes: This table reports summary statistics for the principal components analysis of the sovereign DtD, CDS, yield spreads and credit ratings for all peripheral EA countries. The sample period is 2008Q4 to 2016Q3, the period for which we have the CDS, yields, ratings and sovereign DtD data for all peripheral EA countries.

between the first principal component based on all four measures are roughly $74 \%$ which suggests that the principal source of variation across all sovereign credit risk measures is the same. The second principal component places substantial positive weights on Greece and a negative weight on Ireland. This can be seen as a divergence between Ireland, Greece and the rest of the peripheral countries.

[Figure 7 about here.]

\section{Analysis}

Taking stock of the commonality and differences with other credit risk measures, here we try to understand the information content of the sovereign DtD indicators. In this section, we also test the forward looking nature of sovereign DtD and its predictive ability compared with other credit risk measures.

\subsection{Correlations}

In this subsection, we focus on the correlation among the proposed DtD indicator and the three traditional measures of sovereign risk (yield spread, CDS and rating). Following common practice, the examined co-movements are classified as follows. If $\rho(j), j \in$ $(0, \pm 1, \pm 2, \pm 3, \pm 4)$ denotes the cross correlation between $D t D_{t-j}$ and $X_{t}$, we say that DtD co-moves in the same (opposite) direction of $\mathrm{X}$ if the maximum value of $\rho$ is positive (negative) and not very close to zero. We also say that the DtD indicator is leading, synchronous or lagging $\mathrm{X}$ as $\rho(j)$ reaches a maximum for $j<0, j=0, j>0$. In particular, for $0.5 \leq|\rho(j)|<1$, we use the adjective 'strong', for $0.25 \leq|\rho(j)|<0.5$ we use the adjective 'weak' and, when $0 \leq|\rho(j)|<0.25$ we say that the series are 'not correlated'. The cut-off 
point of 0.25 was chosen because it roughly corresponds to the null hypothesis that the correlation coefficient is zero at $5 \%$ level of significance, given our sample size. ${ }^{20}$

In Table 9, each row displays the correlation coefficient between sovereign DtD at different time lags (from -4 to +4 ) and the given sovereign risk indicator. As can be seen in Part I, in three out of the five cases there is evidence of a strong negative leading relationship between sovereign DtD and sovereign yield spread (Greece, Ireland and Spain), while in the two remaining cases (Italy and Portugal) we find strong negative synchronous association. Regarding the relationship between sovereign DtD and sovereign CDS, in Part II, we detect a strong negative leading association in all the countries under study, indicating that a deterioration of the sovereign solvency (a reduction in DtD) increases the future perceived risk of sovereign bonds. Finally, the evidence presented in Part III suggests a strong negative leading relationship between sovereign DtD and sovereign rating for all countries (i.e., a reduction in DtD generates a future increase in the interest rate paid on government bonds as the market anticipates an increased risk). These results are very insightful since they suggest that although the correlation between the four indices is very high, the DtD indicator seems to lead the evolution of the other three, suggesting that our index may contain useful information for forecasting the traditional indicators.

\subsection{Granger-causality}

The concept of Granger-causality, introduced by Granger (1969) and Sims (1972), is widely used to ascertain the importance of the interaction between two series. One variable is said to Granger-cause some other variable if past information about the latter provides statistically significant information about the former that is not present in its own past information. In this subsection we use vector autoregression (VAR) models for establishing causal links between the proposed DtD indicator and the traditional measures of sovereign risk. In particular, for each equation in the VAR, we make use of the Wald test for the joint significance of each of the other lagged endogenous variables in that equation. The resulting Wald statistics are reported in Table 10 and reinforce the results obtained in the correlations analysis.

As can be seen, in the case of Ireland we find evidence of a bi-directional Grangercausality relationship between DtD and yield spreads, while for the remaining countries under study the results suggest a unidirectional Granger-causality running from DtD to yield spread. Regarding the relationship between sovereign DtD and sovereign CDS, our results suggest weak evidence (at 10\%) of a unidirectional Granger-causality relationship running from CDS to DtD in the case of Italy. Finally, we find evidence of a bi-directional relationship between DtD to rating for Greece, while for the remaining four countries we find statistically significant unidirectional Granger-causality relationships running from DtD to rating. Summing up, the results suggest causality from DtD to two traditional sovereign risk measures: yield spreads and credit rating, but not the other way around.

\footnotetext{
${ }^{20}$ The standard error is approximately $T^{-1 / 2}$, $\mathrm{T}$ being the sample size (68 in our case). Thus two standard errors would be 0.24 .
} 
Table 9: Correlation between sovereign DtD and sovereign yield spreads

\begin{tabular}{lllllllllll} 
Lag & -4 & -3 & -2 & -1 & 0 & 1 & 2 & 3 & 4 \\
\hline
\end{tabular}

Part I: Correlation with sovereign yield spreads

$\begin{array}{lrrrrrrrrr}\text { Greece } & -0.7289 & -0.7409 & -0.7599 & \mathbf{- 0 . 7 7 2 4} & -0.7716 & -0.7512 & -0.7201 & -0.6981 & -0.6927 \\ \text { Ireland } & -0.6679 & -0.7251 & -0.7623 & \mathbf{- 0 . 7 6 5 7} & -0.7393 & -0.6280 & -0.5422 & -0.4602 & -0.3786 \\ \text { Italy } & -0.5164 & -0.6118 & -0.6232 & -0.6822 & \mathbf{- 0 . 7 4 9 8} & -0.6902 & -0.6353 & -0.5909 & -0.5417 \\ \text { Portugal } & -0.5203 & -0.5787 & -0.6675 & -0.7550 & \mathbf{- 0 . 7 8 4 0} & -0.6832 & -0.5967 & -0.5275 & -0.4514 \\ \text { Spain } & -0.6722 & -0.7198 & -0.7345 & \mathbf{- 0 . 7 6 1 4} & -0.7555 & -0.7082 & -0.6515 & -0.6044 & -0.5536\end{array}$

Part II: Correlation with sovereign CDS spreads

$\begin{array}{lrrrrrrrrr}\text { Greece } & \mathbf{- 0 . 7 2 7 5} & -0.6885 & -0.6764 & -0.6653 & -0.5832 & -0.5863 & -0.5096 & -0.4327 & -0.3557 \\ \text { Ireland } & -0.5723 & -0.7095 & \mathbf{- 0 . 7 8 0 1} & -0.7777 & -0.6488 & -0.5579 & -0.4330 & -0.3167 & -0.3167 \\ \text { Italy } & -0.2719 & -0.3954 & -0.4427 & \mathbf{- 0 . 5 7 0 9} & -0.5650 & -0.5081 & -0.3628 & -0.2880 & -0.1742 \\ \text { Portugal } & -0.4369 & -0.5100 & -0.5902 & \mathbf{- 0 . 6 7 9 2} & -0.642 & -0.6125 & -0.5281 & -0.4148 & -0.3163 \\ \text { Spain } & -0.3942 & -0.4718 & -0.5591 & \mathbf{- 0 . 6 3 3 9} & -0.5436 & -0.5184 & -0.3842 & -0.2734 & -0.1771\end{array}$

Part III: Correlation with sovereign credit rating

$\begin{array}{lrrrrrrrrr}\text { Greece } & \mathbf{- 0 . 8 6 9 7} & -0.8597 & -0.8492 & -0.8341 & -0.8191 & -0.7924 & -0.7593 & -0.7399 & -0.7384 \\ \text { Ireland } & \mathbf{- 0 . 5 8 3 3} & -0.5378 & -0.4896 & -0.4188 & -0.3550 & -0.2896 & -0.2359 & -0.1893 & -0.1342 \\ \text { Italy } & \mathbf{- 0 . 6 6 1 5} & -0.6482 & -0.6382 & -0.6108 & -0.6052 & -0.5782 & -0.5557 & -0.5328 & -0.5090 \\ \text { Portugal } & -0.8061 & \mathbf{- 0 . 8 1 4 1} & -0.7400 & -0.6696 & -0.5703 & -0.4972 & -0.4230 & -0.3478 & -0.2938 \\ \text { Spain } & \mathbf{- 0 . 7 1 6 0} & -0.7032 & -0.6650 & -0.6247 & -0.5905 & -0.5491 & -0.4961 & -0.4425 & -0.4097 \\ & & & & & & & & & \end{array}$

Notes: Values in bold letters indicate the highest correlation coefficient for any given row.

\subsection{Generalized Impulse-Response Functions (GIRF)}

In this subsection, we analyse the GIRF to further evaluate the relationship between the proposed DtD indicator and the traditional measures of credit risk. Since the Cholesky-factor identification may be sensitive to ordering, we make use of a generalized VAR decomposition (GVD), invariant to ordering, proposed by Koop et al. (1996) and Pesaran and Shin (1998). GIFR traces out the responsiveness of the dependent variable in the VAR to shocks to each of the variables.

Figures 8 to 10 show the estimated GIRF to a one standard deviation shock, which once again suggests the forward-looking nature of the DtD indicator. As can be seen in Figure 8, in all five cases yield spreads respond negatively to shocks in DtD, and in Italy and Portugal the negative response is progressively reduced to zero. Turning to Figure 9, except for Spain and Italy, we observe a negative response of CDS to DtD shocks that dies out and over time reaches zero. Interestingly, for Greece this initial response is positive.

Finally, in relation to the GIRF for sovereign DtD and sovereign rating, for all countries 
Table 10: Granger causality test (Wald test probabilities)

\begin{tabular}{|c|c|c|c|c|c|}
\hline & Greece & Ireland & Italy & Portugal & Spain \\
\hline Sovereign DtD $\longrightarrow$ Yield spread & $0.0593^{*}$ & $0.0234^{* *}$ & $0.0021^{* * *}$ & $0.0900^{*}$ & $0.0074^{* * *}$ \\
\hline Sovereign DtD $\longrightarrow$ CDS spread & 0.1438 & 0.1370 & 0.3036 & 0.7807 & 0.3318 \\
\hline Sovereign DtD $\longrightarrow$ Credit Rating & $0.0431^{* *}$ & $0.0000^{* * *}$ & $0.0156^{* *}$ & $0.0000^{* * *}$ & $0.0005^{* * *}$ \\
\hline Yield spread $\longrightarrow$ Sovereign DtD & 0.1638 & $0.0643^{*}$ & 0.6911 & 0.9803 & 0.2437 \\
\hline CDS spread $\longrightarrow$ Sovereign DtD & 0.5095 & 0.2589 & $0.0990^{*}$ & 0.3539 & 0.2720 \\
\hline Credit Rating $\longrightarrow$ Sovereign DtD & $0.0573^{*}$ & 0.8098 & 0.2499 & 0.5189 & 0.1370 \\
\hline
\end{tabular}

Notes: The bold letters shows the statistically significant Granger causality linkages. The ***, **, and $*$ stand for significant coefficient at the 1\%,5\%, and $10 \%$ levels, respectively.

under study (Figure 10), we find a negative and increasing response of rating to DtD shocks suggesting that an increase in DtD would result in a better credit classification by the rating agencies. Nevertheless, in the case of Portugal there is evidence of a minor reversion in the negative response after quarter four.

[Figure 8 about here.]

[Figure 9 about here.]

[Figure 10 about here.]

\subsection{Diebold-Yilmaz connectedness measure}

In this subsection, we apply the Diebold-Yilmaz connectedness index methodology (Diebold and Yilmaz $(2009,2012,2014))$ to the four sovereign risk indicators under study. This connectedness measures is based on forecast error variance decompositions from vector autoregressions. The variance decomposition matrix gives us an intuitively appealing connectedness measure, that is the percentage of the future uncertainty in variable $i$ resulting from the shocks in variable $j$.

The full-sample connectedness is presented in Table 11. The $i j^{t h}$ entry of the upper-left $4 \times 4$ submatrix gives the estimated $i j^{\text {th }}$ pair-wise directional connectedness contribution to the forecast error variance of risk indicator $i$ from innovations to risk indicator $j$. Hence, the off-diagonal column sums (labelled "Contribution to others") and row sums (labelled "Contribution from others") give the total directional connectedness to all others from $i$ and from all others to $i$ respectively. The bottom-most row (labelled "Net contribution from others") gives the difference in total directional connectedness (to-from). Finally, the bottom-right element (in boldface) is total connectedness. 
Table 11: Country-wise net pairwise directional connectedness among sovereign risk indicators

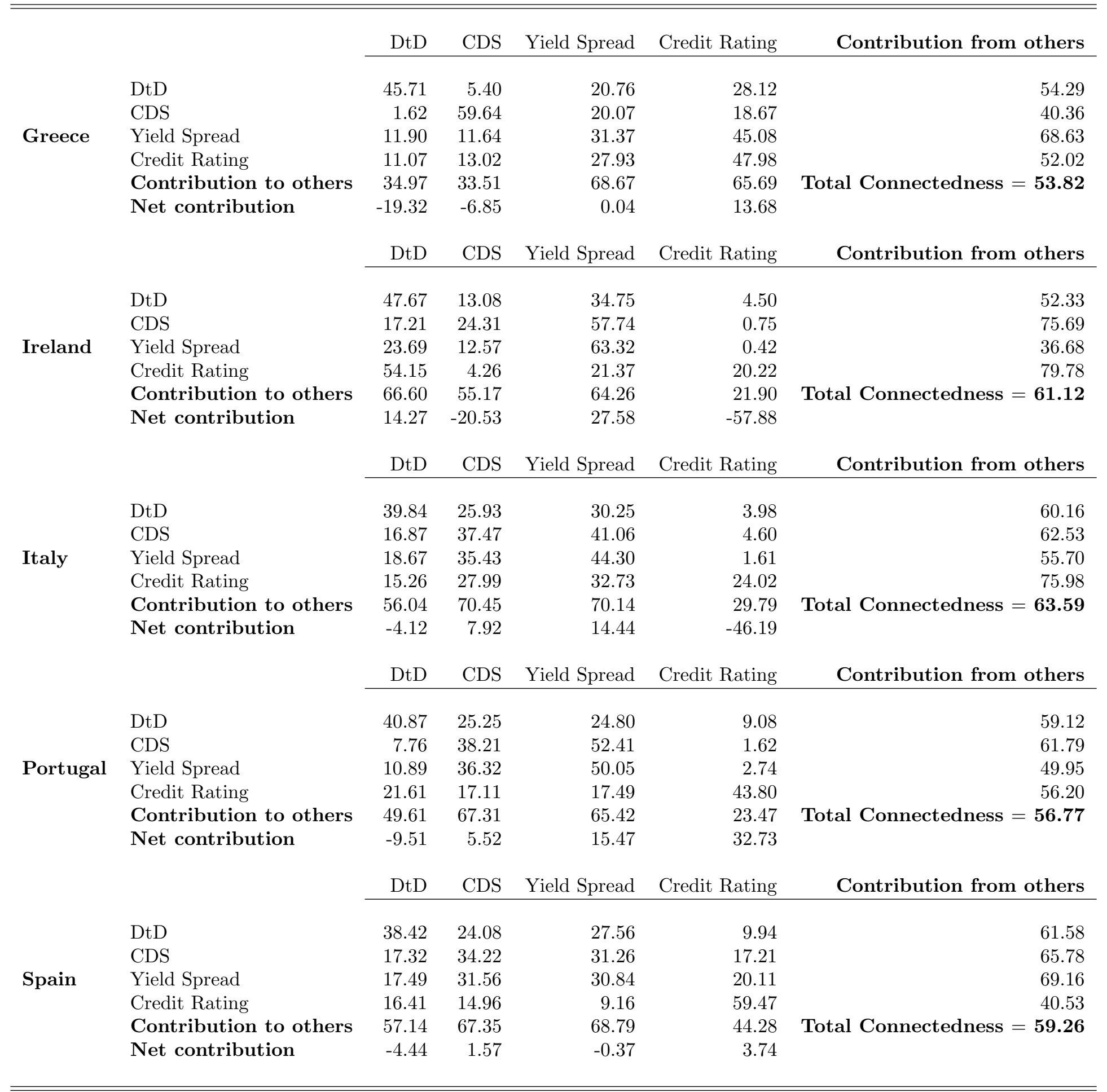


As can be seen, the diagonal elements (own connectedness) are among the largest individual elements in the table, ranging from $31.37 \%$ (Yield spread) to $59.64 \%$ (CDS) in the case of Greece, from 20.22\% (Credit rating) to $63.32 \%$ (Yield spread) in the case of Ireland, from $24.02 \%$ (Credit rating) to $44.30 \%$ (Yield spread) in the case of Italy, from $38.21 \%$ (CDS) to $56.20 \%$ (Credit rating) in the case of Portugal, and from $30.84 \%$ (Yield spread) to $59.47 \%$ (Credit rating) in the case of Spain. Interestingly, the own connectedness measures are smaller than most of the total directional connectedness FROM others, reflecting that these indicators are relatively dependent on each other. That is to say, shocks affecting a particular indicator spread on the other indicators. The total connectedness of the sovereign risk indicators varies between $53.82 \%$ in the case of Greece (indicating that $46.18 \%$ of the variation is due to idiosyncratic shocks) to $63.59 \%$ in Italy (indicating that $36.41 \%$ of the variation is due to idiosyncratic shocks). This result contrasts sharply with the value of $78.3 \%$ obtained by Diebold and Yilmaz (2014) for the total connectedness between US financial institutions and with the value of $97.2 \%$ found by Diebold and Yilmaz (2012) for international financial markets. Our result is closer to the value of $54.23 \%$ found by Fernández-Rodríguez et al. (2016) for the EMU sovereign market volatility.

Regarding the net (TO minus FROM) contribution, our results suggest that, in the case of Greece, DtD and CDS are net receivers of shocks from the other two sovereign risk indicators. For Ireland, we find that DtD and yield spreads are net triggers of shocks, and in Italy, we observe that DtD and credit ratings are net receptors of shocks. In the case of Portugal, CDS and yield spread are found to be net transmitters of shocks. Finally, in the case of Spain, our results indicate that DtD and yield spread are net receivers of shocks.

So far, we have discussed the behaviour of the total connectedness and total net directional connectedness measures for four sovereign credit indicators. However, in order to gain further insights, we have also examined their net pairwise directional connectedness. Figure 11 displays the net pairwise directional connectedness among the sovereign risk indicators for each country under study. As can be seen, yield spreads are the triggers in the connectedness relationships in all countries except Spain, where CDS is the main transmitter of shocks. DtD is a net receiver of shocks from all other indicators in the case of Greece, a receiver of shocks from yield spreads and CDS in the case of Italy, Portugal and Spain, and a net propagator of shocks to credit rating in all countries except Greece. Finally, credit rating is a net receiver of shocks from the other three sovereign risk indicators in the cases of Ireland, Italy and Portugal, and a net trigger of shocks to CDS in the cases of Greece and Spain.

[Figure 11 about here.]

\subsection{Regression analysis}

Finally, in this last subsection, we empirically evaluate the relevance of the variables that have been proposed in the recent theoretical and empirical literature as potential drivers of sovereign risk. To this end, we use a data-based method for obtaining a parsimonious representation of the data-generating process: the general-to-specific approach (for detail, see Hendry (1995)). In this approach, the modeller specifies an initial general model that 
adequately characterizes the empirical evidence within his or her theoretical framework. Starting from a general unrestricted model that captures the essential characteristics of the underlying dataset and contains all relevant variables and sufficient lags, this general model is reduced in complexity by eliminating statistically insignificant variables, checking the validity of the reductions at each stage to ensure the congruence of the finally selected model (see Faust and Whiteman (1997)). This method has proved useful in practice for selecting empirical economic models (see Hendry (2000)).

The dependent variables in our empirical analysis are the proposed DtD indicator and the three traditional measures of sovereign risk (yield spread, CDS, and rating). With regard to the independent variables (Table 12), we consider both fundamental variables and market sentiment variables (see, e.g., Gomez-Puig et al. (2014) and references within). Three of the fundamental variables are used to measure the country's fiscal position; the government debt-to-GDP ratio (DEBT), the government deficit-to-GDP (DEF) and the index of the fiscal stance (FSI) suggested by Polito and Wickens (2011a, 2012a). An increase in DEF and DEBT would signal an intensification in the sovereign risk, while a rise in the FSI would indicate a need for higher fiscal consolidation to achieve a pre-specified debt target at any future time horizon, and therefore would have a positive relationship with sovereign risk. Moreover, the inflation rate (INF) is used as a proxy of the appreciation of the real exchange rate and, thus, the country's loss of competitiveness. A rise in inflation represents a deterioration of competitiveness; therefore, it should increase sovereign risk. The same sign is expected for the unemployment rate (U) which proxies the country's growth potential, while a negative effect might be expected between an increase in the current account balanceto-GDP (CAC) and the sovereign risk.

Turning to the market sentiment variables, we used the implied volatility in the Standard and Poor's 500 index options (VIX) and a synthetic measure of financial market uncertainty in the EA (FMU) as indicators of uncertainty in the global financial and EA financial markets. We also consider the index of economic policy uncertainty (EPU), built by Baker et al. (2013), to assess whether policy uncertainty has influenced sovereign risk, and a country-level index of financial stress (CLIFS) to evaluate the degree of financial stress in national financial markets. A positive sign is expected for their respective coefficients. Finally, the consumer confidence indicator is used to gauge economic agents' perceptions of future economic activity. It seems reasonable to expect a negative relationship between this and sovereign risk, since an increase in consumer confidence may lead to a rise in investor confidence in the economy's potential for growth. 
Table 12: Variables that measure macroeconomic fundamentals and market sentiments

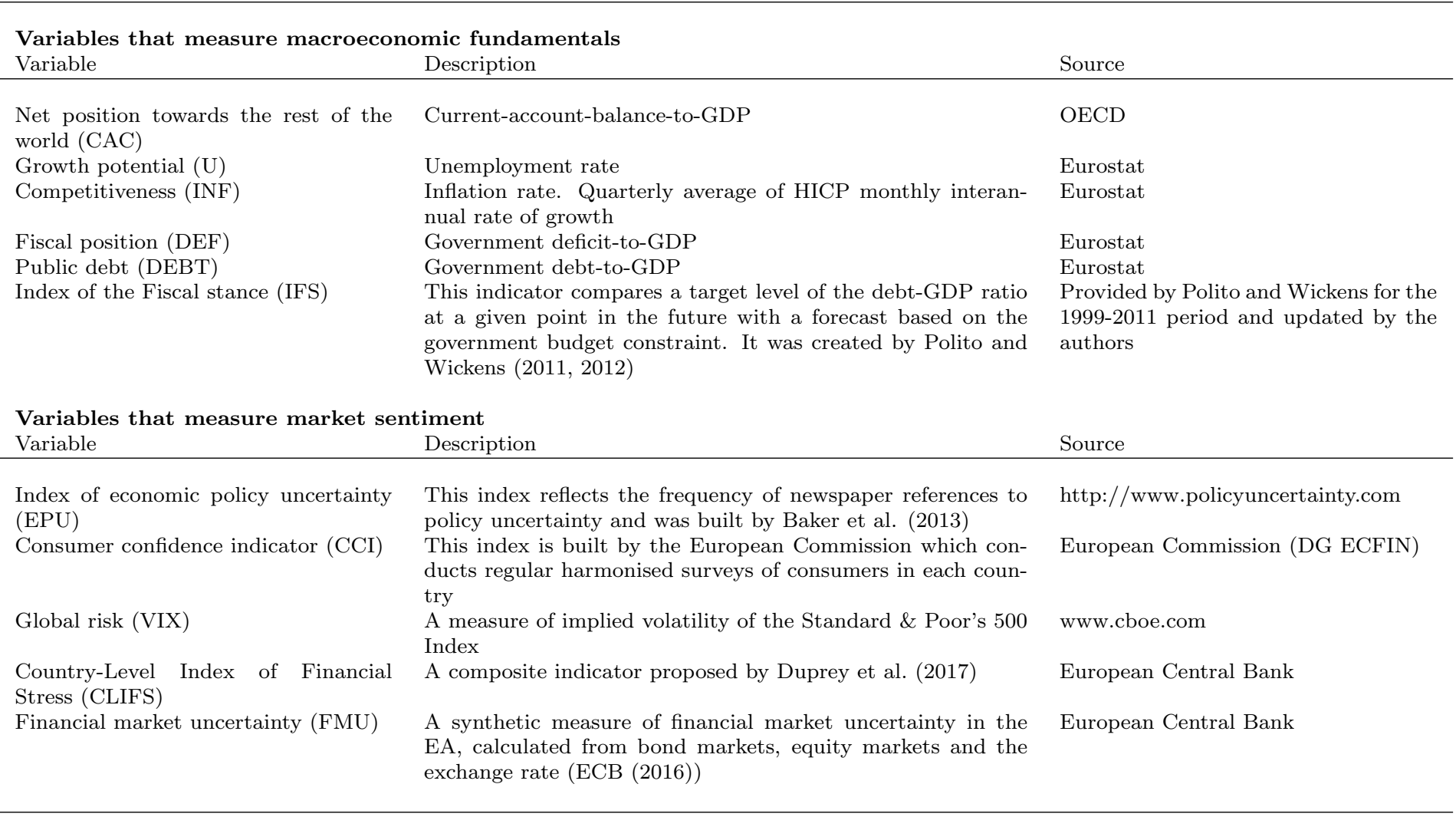

Tables 13 reports the empirical results. As can be seen, all explanatory variables turn out to be significant and their signs are in accordance with the literature. ${ }^{21}$ An important result of these regression analyses is that, while market sentiment variables seem to play a dominant role in determining traditional measures of sovereign risk, macroeconomic fundamentals are identified as the main drivers of sovereign risk, as measured by the proposed DtD indicator. These results suggest that the DtD indicator isolates the fundamental and fiscal situation of the country better than the other three risk indicators, which are influenced much more by market sentiment and uncertainty.

\footnotetext{
${ }^{21}$ Recall that, by construction, a reduction in DtD indicates an increase in sovereign risk.
} 
Table 13: Regression results

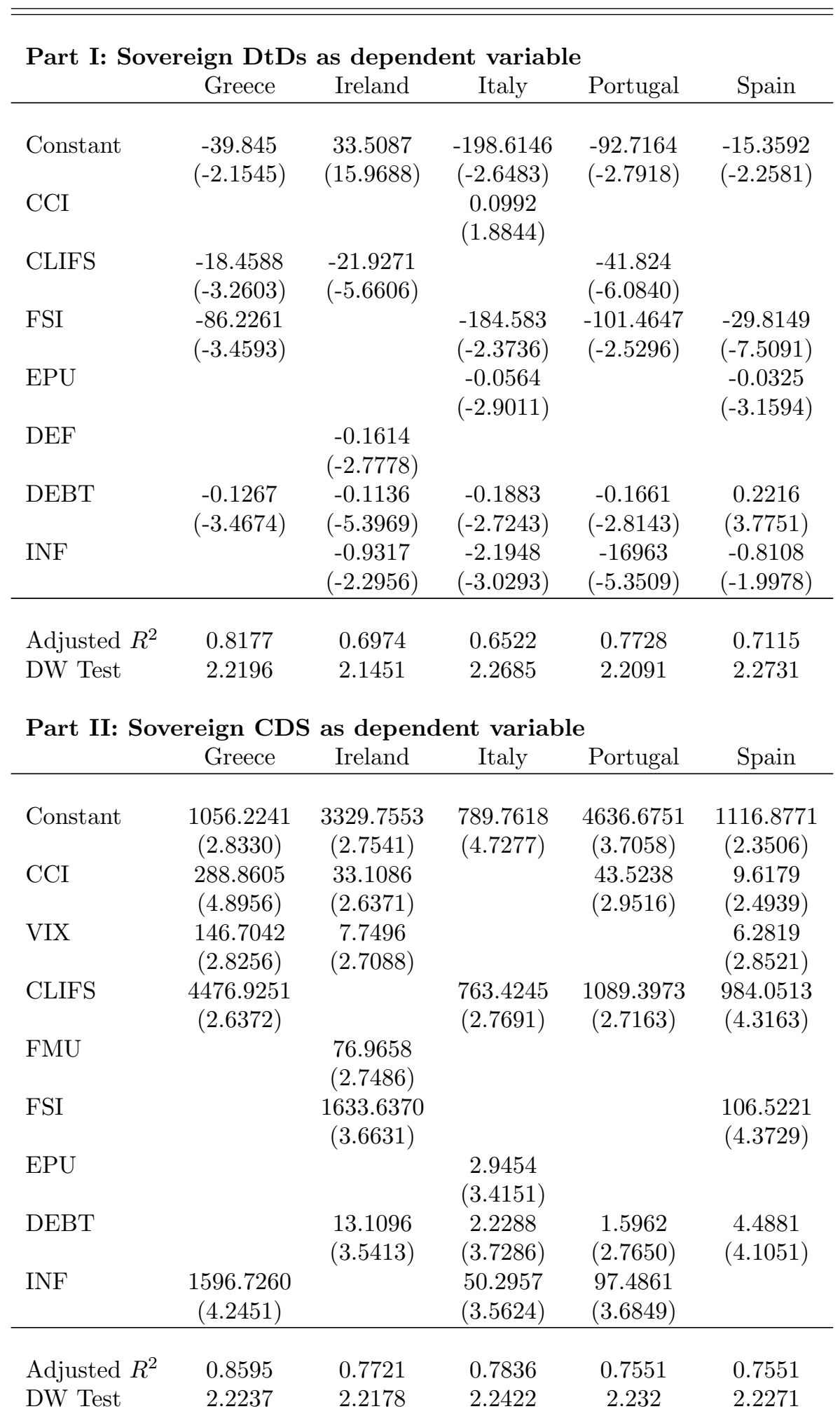


Part III: Sovereign yield spreads as dependent variable

\begin{tabular}{|c|c|c|c|c|c|}
\hline & Greece & Ireland & Italy & Portugal & Spain \\
\hline Constant & & $\begin{array}{c}3.4359 \\
(3.4312)\end{array}$ & $\begin{array}{c}5.6094 \\
(5.1998)\end{array}$ & $\begin{array}{c}89.217 \\
(4.5158)\end{array}$ & $\begin{array}{l}4.0921 \\
(3.124)\end{array}$ \\
\hline CCI & & & $\begin{array}{c}-0.0308 \\
(-3.9038)\end{array}$ & $\begin{array}{c}0.8185 \\
(-2.7399)\end{array}$ & \\
\hline VIX & $\begin{array}{c}0.2513 \\
(3.1691)\end{array}$ & & $\begin{array}{c}0.026 \\
(2.7820)\end{array}$ & $\begin{array}{c}0.2304 \\
(2.7747)\end{array}$ & $\begin{array}{c}0.0963 \\
(4.2712)\end{array}$ \\
\hline CLIFS & $\begin{array}{l}20.3810 \\
(3.6375)\end{array}$ & $\begin{array}{c}2.2155 \\
(2.7941)\end{array}$ & $\begin{array}{c}2.1031 \\
(2.7661)\end{array}$ & $\begin{array}{l}12.4637 \\
(3.4600)\end{array}$ & $\begin{array}{c}7.2661 \\
(3.2550)\end{array}$ \\
\hline $\mathrm{FMU}$ & & $\begin{array}{c}0.6990 \\
(2.8123)\end{array}$ & $\begin{array}{c}0.2438 \\
(2.7362)\end{array}$ & & \\
\hline FSI & $\begin{array}{c}9.9387 \\
(3.4181)\end{array}$ & $\begin{array}{c}0.1389 \\
(3.9837)\end{array}$ & $\begin{array}{c}2.1032 \\
(2.8121)\end{array}$ & $\begin{array}{l}37.7502 \\
(4.3383)\end{array}$ & $\begin{array}{c}1.0803 \\
(3.5735)\end{array}$ \\
\hline $\mathrm{EPU}$ & $\begin{array}{c}0.0934 \\
(3.4131)\end{array}$ & & $\begin{array}{c}0.0156 \\
(3.7134)\end{array}$ & & \\
\hline DEF & & $\begin{array}{c}0.0262 \\
(-2.9370)\end{array}$ & & & \\
\hline DEBT & $\begin{array}{c}0.0579 \\
(2.7892)\end{array}$ & & $\begin{array}{c}0.025 \\
(3.1542)\end{array}$ & $\begin{array}{c}0.2549 \\
(3.1112)\end{array}$ & $\begin{array}{c}0.0068 \\
(2.7653)\end{array}$ \\
\hline INF & $\begin{array}{c}0.6181 \\
(2.3593) \\
\end{array}$ & & & & $\begin{array}{c}0.2608 \\
(2.8981) \\
\end{array}$ \\
\hline Adjusted $R^{2}$ & 0.7963 & 0.6715 & 0.7589 & 0.7154 & 0.847 \\
\hline DW Test & 2.2712 & 2.2246 & 2.2137 & 2.2142 & 2.205 \\
\hline
\end{tabular}

Part IV: Sovereign credit ratings as dependent variable

\begin{tabular}{lccccc} 
& Greece & Ireland & Italy & Portugal & Spain \\
\hline \multirow{2}{*}{ Constant } & 8.0092 & 1.9588 & 87.9446 & 83.0416 & \\
& $(3.5636)$ & $(3.3996)$ & $(5.5008)$ & $(5.6072)$ & \\
CCI & -0.0232 & -0.0258 & & -0.0708 & -0.0751 \\
& $(-1.9934)$ & $(-3.8802)$ & & $(-2.1954)$ & $(-3.2737)$ \\
VIX & 0.0856 & 0.0161 & 0.0221 & 0.0202 & 0.0532 \\
& $(2.7640)$ & $(2.7541)$ & $(2.8178)$ & $(2.8086)$ & $(2.9683)$ \\
CLIFS & 7.1819 & 3.3777 & 1.4153 & 8.9597 & 8.5063 \\
FSI & $(3.5540)$ & $(3.2121)$ & $(2.7448)$ & $(3.4548)$ & $(3.8129)$ \\
& & & 67.995 & 58.0251 & \\
EPU & 0.0177 & & $(3.4965)$ & $(3.5573)$ & \\
& $(3.0587)$ & & & & 0.0057 \\
DEBT & 0.1369 & 0.067 & 0.0286 & 0.3945 & 0.1627 \\
\multirow{2}{*}{ INF } & $(3.0109)$ & $(2.9817)$ & $(2.8517)$ & $(3.0699)$ & $(3.7364)$ \\
& & & & & 0.1944 \\
& & & & & \\
Adjusted $R^{2}$ & 0.8081 & 0.8432 & 0.8314 & 0.8458 & 0.8374 \\
DW Test & 2.2239 & 2.2716 & 2.2766 & 2.1798 & 2.7612 \\
& & & & & \\
\hline \hline
\end{tabular}


In order to gauge the predictive power of our basic model and to assess how each explanatory variable contributes to the explanation of the dependent variable, we perform stochastic dynamic simulations. Table 14 reports the results for each sovereign risk indicator under study. Column 2 represents the actual values of the dependent variables averaged over the period of the analysis, while column 3 shows the averaged predicted values. The remaining columns present the contribution of the explanatory variables across countries. As can be seen, our results suggest that while macroeconomic fundamentals are the main drivers of sovereign risk measured by the proposed DtD indicator (explaining an average of $88.42 \%$ ), market sentiment variables are identified as the key determinants of the traditional measures of credit risk (contributing to explain, on average, $75.05 \%$ of the CDS risk indicator in the sample, $61.80 \%$ of the yield spreads and $62.89 \%$ of the credit ratings).

Table 14: Predictive power and relative contributions of the explanatory variables

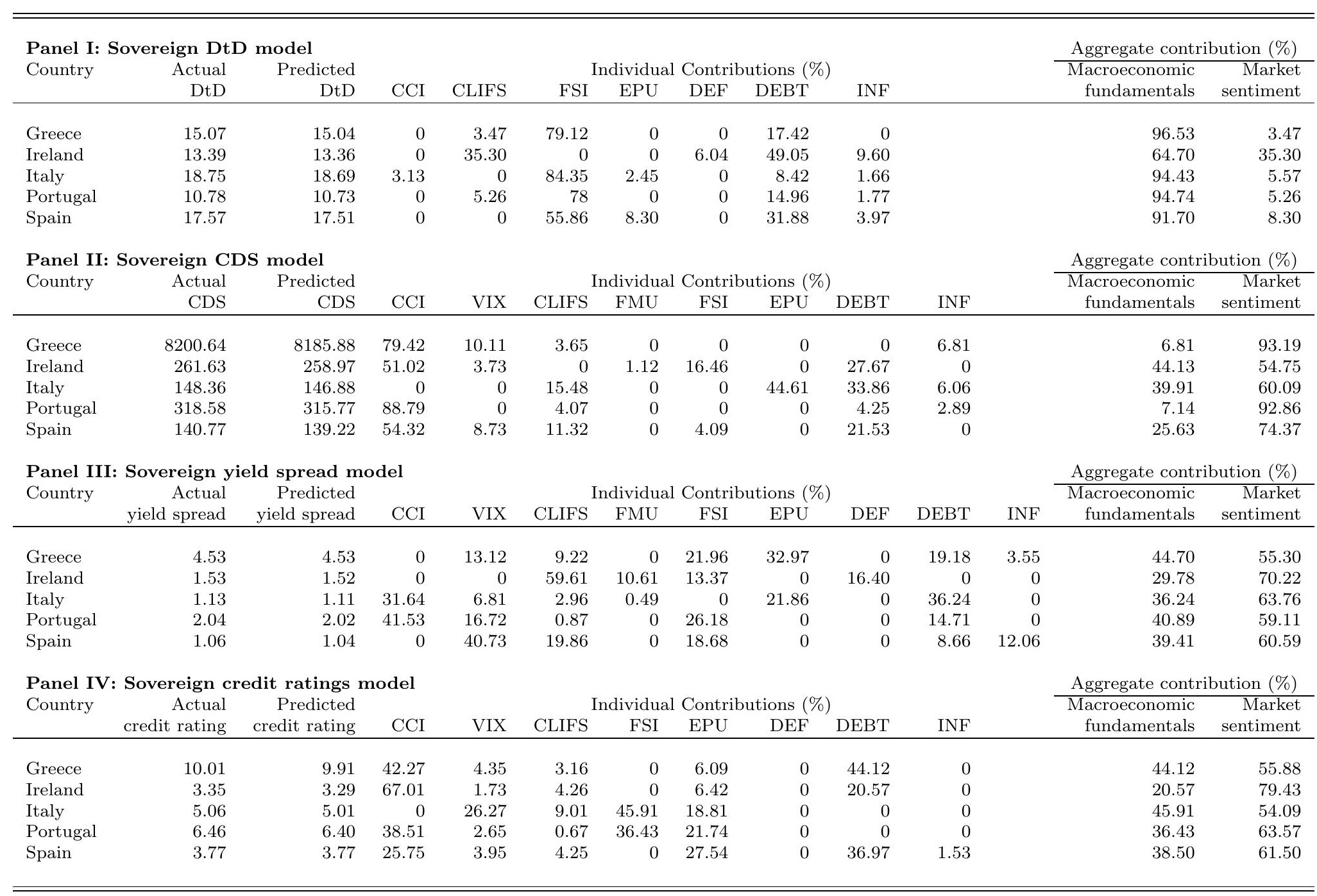




\section{Concluding remarks}

Based on the theory and practice of modern contingent claims methodology, this paper proposes a modified contingent claims model that incorporates the priority structure of creditors in measuring sovereign credit risk for euro area peripheral countries. These new risk indicators model an important element - the total debt held by multilateral creditors (i.e., the ECB, IMF, ESM etc.), which provides additional information and helps to reconcile the country's credit risk with its underlying economic fundamentals.

By analysing the behaviour and fluctuations of sovereign DtD, our results show that the new credit risk indicator is less correlated across countries than the existing market based credit risk indicators (i.e., CDS spreads, sovereign yield spreads and credit ratings). Even though they share a highly correlated underlying factor linked with global risk and uncertainty, its weight diminishes in times of crisis. Sovereign DtD shows better predictive ability (1-4 quarters) and very high correlations for most of the peripheral EA countries. The Granger causality test reveals the direction of causality running from sovereign DtDs to yield spreads and credit ratings (and not the other way round), suggesting better information content.

Generalized VAR also provides evidence of the additional information content of the proposed sovereign risk indicator in explaining the traditional ones when accounting for dynamic interrelationships between them. When analysing the connectedness between the sovereign risk indicators using the framework proposed by Diebold and Yilmaz $(2012,2014)$, we found system-wide values ranging from $53.82 \%$ in the case of Greece to $63.59 \%$ in Italy. Finally, the regression analysis suggests that macroeconomic fundamentals are the main drivers of sovereign risk measured by the proposed sovereign DtD indicator, while market sentiment variables are the key determinants of the traditional measures of credit risk.

Our results show that the alternative sovereign credit risk measure proposed has a meaningful signalling power in assessing sovereign vulnerabilities, suggesting a potential role in the policy makers' tool box for monitoring risks and vulnerabilities. This is relevant given the recent trend among policy makers to give a greater focus to financial stability analysis, financial system resilience, crisis prevention, and management.

There are several natural extensions to our analysis. Policies aimed at reducing sovereign risk should be explored in detail in future work. Going forward, the DtD framework could be extended beyond the sovereign context. In addition, given the flexibility of this framework, the financial sector and sovereign risk analysis could be integrated with macro-financial feedbacks in order to design monetary and fiscal policies.

\section{References}

Acharya, V.and Drechsler, I., Schnabl, P., 2014. A pyrrhic victory? Bank bailouts and sovereign credit risk. The Journal of Finance 69, 2689-2739.

Acharya, V., Steffen, S., 2015. The "greatest" carry trade ever? Understanding eurozone bank risks. Journal of Financial Economics 115 (2), 215-236.

Agarwal, V., Taffler, R., 2008. Comparing the performance of market based and accounting based bankruptcy prediction models. Journal of Banking and Finance 32, 1541-1551. 
Aizenman, J., Hutchison, M., Jinjarak, Y., 2013. What is the risk of European sovereign debt defaults? Fiscal space, CDS spreads and market pricing of risk. Journal of International Money and Finance 34, $37-59$.

Allen, F.and Beck, T., Carletti, E., Lane, P. L., Schoenmaker, D., Wagner, W., 2011. Cross-border banking in europe: Implications for financial stability and macroeconomic policies. London: Centre for Economic Policy Research.

Altman, E., 1968. Financial ratios, discriminant analysis and the prediction of corporate bankruptcy. Journal of Finance 23, 589-609.

Altman, E., Katz, S., 1976. Statistical bond rating classification using financial and accounting data. In: Schiff, M.and Sorter, G. (eds). Proceedings of the Conference on Topical Research in Accounting, New York University Press, New York, 205-239.

Ang, A., Bekaert, G., 2002. International asset allocation with regime shifts. Review of Financial Studies 15 (4), 1137-1187.

Angelini, P., Nobili, A., Picillo, C., 2011. The Interbank Market after August 2007: What has changed, and why? Journal of Money, Credit and Banking 43 (5), 923-958.

Aristei, D.and Martelli, D., 2014. Sovereign bond yield spreads and market sentiment and expectations: Empirical evidence from Euro area countries. Journal of Economics and Business 76, 55-84.

Badaoui, S., Cathcart, L., El-Jahel, L., 2013. Do sovereign credit default swaps represent a clean measure of sovereign default risk? A factor model approach. Journal of Banking and Finance 37, 2392-2407.

Baker, S. R., Bloom, N., Davis, S. J., 2013. Measuring economic policy uncertainty. Working Paper 13-02, Booth School of Business, The University of Chicago, Chicago.

Bartholomew, P., Whalen, G., 2005. Fundamentals of systemic risk. Research in Financial Services: Banking, Financial Markets, and Systemic Risk 7, 3-17.

Battistini, N., Pagano, M., Simonelli, S., 2013. Systemic risk and home bias in the euro area. European Commission, European Economy, Economic Papers, No. 494.

Beirne, J., Fratzscher, F., 2013. The pricing of sovereign risk and contagion during the European sovereign debt crisis. Journal of International Money and Finance 34, 60-82.

Belke, A., 2013. Towards a genuine Economic and Monetary Union - Comments on a roadmap. Politics and Governance 1 (1), 48-65.

Belke, A., Gros, D., 2001. Real impacts of intra-European exchange rate variability: A case for EMU? Open Economies Review 12 (3), 231-264.

Belke, A., Gros, D., 2015. Banking union as a shock absorber. Research On Money in the Economy, Discussion Paper Series No 2015-02, April 2015.

Belke, A., Schneider, J., 2013. Portfolio choice of financial investors and European business cycle convergence - a panel analysis for EU countries. Empirica 40 (1), 175-196.

Bharath, S. T., Shumway, T., 2008. Forecasting default with the Merton's distance-to-default model. Review of Financial Studies 21, 1339-1369.

Black, F., Scholes, M., 1973. The pricing of options and corporate liabilities. Journal of Political Economy 81, 637-654.

Blanco, R., 2001. The Euro-area government securities markets: Recent developments and implications for market functioning. Working Paper 0120, Banco de España.

Blommestein, H.and Eijffinger, S., Qia, Z., 2016. Regime-dependent determinants of Euro area sovereign CDS spreads. Journal of Financial Stability 22, 10-21.

Blume, M., Lim, F., Mackinlay, A., 1998. The declining credit quality of U.S. corporate debt: Myth or reality? Journal of Finance 53, 1389-1413.

Boumparis, P.and Milas, C., Panagiotidis, T., 2017. Economic policy uncertainty and sovereign credit rating decisions: Panel quantile evidence for the Eurozone. Journal of International Money and Finance 79, 3971.

Boysen-Hogrefe, J., 2017. Risk assessment on euro area government bond markets The role of governance. Journal of International Money and Finance 73, 104-111.

Breuss, F., Roeger, W., Veld, J., 2015. The stabilizing properties of a European banking union in case of 
financial shocks in the euro area. European Commission, Directorate-General Economic and Financial Affairs, Economic Papers 550, June 2015.

Broto, C., Molina, L., 2016. Sovereign ratings and their asymmetric response to fundamentals. Journal of Economic Behavior and Organization 130, 206-224.

Broto, C., Perez-Quiros, G., 2015. Disentangling contagion among sovereign CDS spreads during the European debt crisis. Journal of Empirical Finance 32, 165-179.

Campbell, J., Hilscher, J., Szilagyi, J., 2008. In search of distress risk. Journal of Finance 63, 2899-2939.

Campbell, J., Hilscher, J., Szilagyi, J., 2011. Predicting financial distress and the performance of distressed stocks. Journal of Investment Management 9, 1-21.

Chan, N. M., Getmansky, M., Haas, S. M., Lo, A. W., 2006. Systemic risk and hedge funds. In: Carey, M., Stulz, R.M. (eds.). The Risks of Financial Institutions. University of Chicago Press, Chicago/London, 235-238.

Chava, S., Jarrow, R., 2004. Bankruptcy prediction with industry effects. Review of Finance 8, 537-539.

Cochrane, J., 2005. Money as stock. Journal of Monetary Economics 52 (3), 502.

Crosbie, P. J., Bohn, J. R., 2003. Modeling default risk. Moody's KMV Company.

De Bandt, O., Hartmann, P., 2000. Systemic risk: A survey. Working Paper 35, European Central Bank, Frankfurt.

De Grauwe, P., 2012. The governance of a fragile eurozone. The Australian Economic Review 45 (2), $255-268$.

De Grauwe, P., Ji, Y., 2013. Self-fulfilling crises in the eurozone: an empirical test. Journal of International Money and Finance 34, 15-36.

De Nicolo, G., Kwast, M., 2002. Systemic risk and financial consolidation: are they related? Journal of Banking and Finance 26, 861-880.

Diebold, F. X., Yilmaz, K., 2009. Measuring financial asset return and volatility spillovers, with application to global equity markets. Economic Journal 119, 158-171.

Diebold, F. X., Yilmaz, K., 2012. Better to give than to receive: Predictive directional measurement of volatility spillovers. International Journal of Forecasting 28, 57-66.

Diebold, F. X., Yilmaz, K., 2014. On the network topology of variance decompositions: Measuring the connectedness of financial firms. Journal of Econometrics 182 (1), 119-134.

Duggar, E., Mitra, S., 2007. External linkages and contagion risk in Irish banks. Working Papers 07/44, International Monetary Fund, Washington, DC.

Duprey, T., Klaus, B., Peltonen, T. A., 2017. Dating systemic nancial stress episodes in the EU countries. Journal of Financial Stability 32, 30-56.

ECB, 2016. The impact of uncertainty on activity in the euro area. European Central Bank, Economic Bulletin No. 8, 55-74.

Eichengreen, B., Hausmann, R., Panizza, U., 2002. Original sin: The pain, the mystery, and the road to redemption. Paper presented at Inter-American Development Bank conference, "Currency and Maturity Matchmaking: Redeeming Debt from Original Sin." Washington, November.

European Central Bank, 2012. Distance to default for large and complex banking groups. Financial Stability Review, December, 147.

European Central Bank, 2013. How has macroeconomic uncertainty in the euro area evolved recently?, Monthly Bulletin October, 44-48.

Fabozzi, F.J.and Giacometti, R., Tsu, N., 2016. Factor decomposition of the Eurozone sovereign CDS spreads. Journal of International Money and Finance 65, 1-23.

Faust, J., Whiteman, C. H., 1997. General-to-specific procedure for fitting a data-admissble, theory-inspired, congruent, parsimonious, encompassing, weakly exogenous, identified, structural model to the dgp: A translation and critique. International Finance Discussion Papers 1997-576, Board of Governors of the Federal Reserve System, Washington D. C.

Favero, C., Missale, A., 2012. Sovereign spreads in the eurozone: which prospects for a Eurobond? Economic Policy 27 (70), 231-273.

Fernández-Rodríguez, F., Gómez-Puig, M., Sosvilla-Rivero, S., 2016. Using connectedness analysis to assess financial stress transmission in EMU sovereign bond market volatility. Journal of International Financial 
Markets, Institutions and Money 43, 126-145.

Ferri, G., Liu, L., Stiglitz, J., 1999. The procyclical role of rating agencies: evidence from the East Asian crisis. Economic Notes 28, 335-355.

Fontana, A., Scheicher, M., 2016. An analysis of euro area sovereign CDS and their relation with government bonds. Journal of Banking and Finance 62, 126-140.

Gapen, M. T., Gray, D. F., Lim, C. H., Xiao, Y., 2005. Measuring and analyzing sovereign risk with contingent claims. Working Papers 05/155, International Monetary Fund, Washington, DC.

Georgoutsos, D. A., Migiakis, P. M., 2013. Heterogeneity of the determinants of Euro-area sovereign bond spreads: What does it tell us about financial stability? Journal of Banking and Finance 37, 4650-4664.

Goldstein, M., 1995. International financial markets and systemic risk. Institute of International Economics Mimeo, Washington, DC.

Gomez-Puig, M., Sosvilla-Rivero, S., Ramos-Herrera, M., 2014. An update on EMU sovereign yield spread drivers in times of crisis: A panel data analysis. North American Journal of Economics and Finance 30, 133-153.

Goodhart, C. A. E., 1975a. Monetary relationships: A view from threadneedle street. Papers in Monetary Economics, Volume I, Reserve Bank of Australia.

Goodhart, C. A. E., 1975b. Problems of monetary management: The UK experience. Papers in Monetary Economics, Volume I, Reserve Bank of Australia.

Grande, G., Levy, A., Panetta, F., Zaghini, A., 2013. Public guarantees on bank bonds: Effectiveness and distortions. in J. R. LaBrosse, R. Olivares-Caminal, D. Singh (eds.), Financial crisis containment and government guarantees, Cheltenham, UK: Edward Elgar.

Granger, C. W. J., 1969. Investigating causal relations by econometric models and cross-spectral methods. Econometrica 37 (3), 424-438.

Gray, D., Jobst, A., 2010. Lessons from the financial crisis on modeling systemic risk and sovereign risk. In: Berd, Arthur (eds.), Lessons from the Financial Crisis. RISK Books, London.

Gray, D., Jobst, A., Malone, S., 2010. Quantifying systemic risk and reconceptualizing the role of finance for economic growth. Journal of Investment Management 8, 90-110.

Gray, D., Malone, S., 2008. John Wiley and Sons, Chichester, West Sussex, England. Macrofinancial Risk Analysis.

Gray, D., Merton, R., Bodie, Z., 2007. New framework for measuring and managing macrofinancial risk and financial stability. Working Paper 13607, National Bureau of Economic Research, Cambridge, MA.

Gray, D., Walsh, J., 2008. Factor model for stress-testing with a contingent claims model of the Chilean banking system. Working Papers 08/89, International Monetary Fund, Washington, DC.

Gropp, R., Vesala, J., Vulpers, G., 2006. Equity and bond market signals as leading indicators of bank fragility. Journal of Money, Credit and Banking 38, 399-428.

Harada, K., Ito, T., 2008. Did mergers help Japanese mega-banks avoid failure? Analysis of the distanceto-default of banks. Working Paper 14518, National Bureau of Economic Research, Cambridge, MA.

Harada, K., Ito, T., Takahashi, S., 2010. Is the distance-to-default a good measure in predicting bank failures? Case studies. Working Paper 16182, National Bureau of Economic Research, Cambridge, MA.

Hendry, D. F., 1995. Dynamic econometrics. Oxford University Press, Oxford.

Hendry, D. F., 2000. Epilogue: The success of general-to-specific model selection. In Econometrics: Alchemy or Science? Oxford: Oxford University Press (pp. 467-490.

Hillegeist, S. A., Keating, E., Cram, D. P., Lunstedt, K. G., 2004. Assessing the probability of bankruptcy. Review of Accounting Studies 9, 5-34.

Horvitz, P., Ward, R., 1987. Monetary policy and the financial system. 6th edition, Prentice Hall Inc., Englewoods Cliffs, NJ.

International Monetary Fund, 2013. Old risks, new challenges. Chapter 2 on Sovereign CDS Market (April).

Jessen, C., Lando, D., 2015. Robustness of distance-to-default. Journal of Banking and Finance 50, 493-505.

Jobst, A., Gray, D., 2013. Systemic contingent claims analysis: Estimating market-implied systemic risk. Working Papers 13/54, International Monetary Fund, Washington, DC.

Jorion, P., 2006. Bank trading risk and systemic risk. In Carey, M. and Stulz, R. M. (eds.) The Risks 
of Financial Institutions - A National Bureau of Economic Research Conference Report. University of Chicago Press, Chicago, 29-58.

Kambhu, J., Weidman, S., Krishnan, N., 2007. New directions for understanding Systemic Risk: A report on a conference cosponsored by the Federal Reserve Bank of New York and the National Academy of Sciences. The National Academies Press, Washington, DC.

Kaplan, R., Urwitz, G., 1979. Statistical models of bond ratings: A methodological inquiry. Journal of Business 52, 231-261.

Kaufman, G. G., 1995. Comment on systemic risk. Research in Financial Services: Banking, Financial Markets, and Systemic Risk 7, 47-52.

Kealhofer, S., 2003. Quantifying credit risk I: Default prediction. Financial Analyst Journal 59 (1), 30-44.

Kletzer, K., Wright, B., 2000. Sovereign debt as intertemporal barter. The American Economic Review 90 (3), 621-639.

Klose, J., Weigert, B., 2014. Sovereign yield spreads during the euro crisis: Fundamental factors versus redenomination risk. International Finance 17 (1), 25-50.

Koop, G., Pesaran, M. H., Potter, S. M., 1996. Impulse response analysis in non-linear multivariate models. Journal of Econometrics 74, 119-147.

Kopf, C., 2012. Restoring financial stability in the eurozone. CEPS Policy Briefs.

Koutsomanoli-Filippakia, A., Mamatzakis, E., 2009. Performance and Merton-type default risk of listed banks in the EU: A panel VAR approach. Journal of Banking and Finance 33, 2050-2061.

Longstaff, F. A., Pan, J., Pedersen, L. H., Singleton, K. J., 2011. How sovereign is sovereign credit risk? American Economic Journal: Macroeconomics 3 (2), 75-103.

Martha, R., 1990. Preferred creditor status under international law: the case of the International Monetary Fund. International and Comparative Law Quarterly 39 (4), 801-826.

Merler, S., Pisani-Ferry, J., 2012. Who's afraid of sovereign bonds. Bruegel Policy Contribution, 2012-02, February 2012.

Merton, R., Billio, M., Getmansky, M., Gray, D., Lo, A., Pelizzon, L., 2013. On a new approach for analyzing and managing macrofinancial risks. Financial Analysts Journal 69 (2), 22-33.

Merton, R. C., 1974. On the pricing of corporate debt: The risk structure of interest rates. Journal of Finance 29, 449-470.

Merton, R. C., 1977. An analytical derivation of the cost of deposit insurance and loan guarantees. An application of modern option pricing theory. Journal of Banking and Finance 1, 3-11.

Monfort, B.and Mulder, C., 2000. Using credit ratings for capital requirements on lending to emerging market economies: Possible impact of a new Basel Accord. IMF Working Paper 00/69.

Mora, N., 2006. Sovereign credit ratings: Guilty beyond reasonable doubt? Journal of Banking and Finance 30, 2041-2062.

Oderda, G., Dacorogna, M., Jung, T., 2003. Credit risk models: Do they deliver their promises? A quantitative assessment. Review of Banking, Finance and Monetary Economics 32, 177-195.

Ohlson, J. A., 1980. Financial ratios and the probabilistic prediction of bankruptcy. Journal of Accounting Research 18, 109-131.

Ongena, S., Popov, A., Van Horen, N., 2016. The invisible hand of the government: 'Moral suasion' during the European sovereign debt crisis. ECB Working Paper 1937, July 2016.

Paniagua, J., Sapena, J., Tamarit, C., 2017. Sovereign debt spreads in EMU: The time-varying role of fundamentals and market distrust. Journal of Financial Stability 33, 187-206.

Pesaran, M. H., Shin, Y., 1998. Generalized impulse response analysis in linear multivariate models. Economic Letters 58, 17-29.

Polito, V., Wickens, M., 2011a. Assessing the fiscal stance in the european union and the united states. Economic Policy 26, 599-647.

Polito, V., Wickens, M., 2011b. Assessing the fiscal stance in the European Union and the United States, 1970-2011. Economic Policy 26, 599-647.

Polito, V., Wickens, M., 2012a. A model-based indicator of the fiscal stance. European Economic Review $56,526-551$. 
Polito, V., Wickens, M., 2012b. A model-based indicator of the fiscal stance. European Economic Review $56,526-551$.

Qia, M., Zhangb, X., Zhao, X., 2014. Unobserved systematic risk factor and default predictio. Journal of Banking and Finance 49, 216-227.

Rochet, J. C., Tirole, J., 1996. Interbank lending and systemic risk. Journal of Money, Credit and Banking $28,733-762$.

Roubini, N., Setser, B., 2004. Bailouts or bail-ins? Responding to financial crises in emerging economies. Peterson Institute for International Economics.

Rubia, A., Sanchis-Marco, L., Serrano, P., 2016. Market frictions and the pricing of sovereign credit default swaps. Journal of International Money and Finance 60, 223-252.

Saldias, M., 2013. Systemic risk analysis using forward-looking distance-to-default series. Journal of Financial Stability 9, 498-517.

Schich, S., Lindh, S., 2012. Implicit guarantees for bank debt: Where do we stand? OECD Journal: Financial Market Trends 2012/1.

Schoenmaker, D., 2013. Governance of International Banking: The Financial Trilemma. Oxford University Press, Oxford.

Shumway, T., 2001. Forecasting bankruptcy more accurately: A simple hazard model. Journal of Business $74,101-124$.

Silvapulle, P., Fenech, J. P., Thomas, A., Broo, R., 2016. Determinants of sovereign bond yield spreads and contagion in the peripheral EU countries. Economic Modelling 58, 83-92.

Sims, C., 1999. Domestic currency denominated government debt as equity in the primary surplus. Paper presented at the Latin American meetings of the Econometric Society, Cancun, Mexico. August 1999.

Sims, C. A., 1972. Money, income, and causality. The American Economic Review 62 (4), 540-552.

Singh, M. K., Gomez-Puig, M., Sosvilla-Rivero, S., 2015. Bank risk behavior and connectedness in EMU countries. Journal of International Money and Finance 57, 161-184.

Singh, M. K., Gomez-Puig, M., Sosvilla-Rivero, S., 2016. Sovereign-bank linkages: Quantifying directional intensity of risk transfers in EMU countries. Journal of International Money and Finance 63, 137-164.

Sinn, H.-W., Wollmershäuser, T., 2012. Target loans, current account balances and capital flows: the ECB's rescue facility. International Tax and Public Finance 19 (4), 468-508.

Soudis, D., 2016. Determinants of sovereign bonds ratings: A robustness analysis. Bulletin of Economic Research 69 (2), 164-177.

Steinkamp, S., Westermann, F., 2014. The role of creditor seniority in Europe's sovereign debt crisis. Economic Policy 29 (79), 495-552.

Thomas, S., Singh, M. K., Aggarwal, N., 2012. Do changes in distance-to-default anticipate changes in the credit rating? Working Paper 2012-10, Indira Gandhi Institute of Development Research, Mumbai.

Vasicek, O., 1984. Credit valuation. KMV Corporation.

Vassalou, M., Yuhang, X., 2004. Default risk in equity returns. Journal of Finance 59, 831-868.

Weidemaier, M., Scott, R., Gulati, M., 2013. Origin myths, contracts, and the hunt for pari passu. Law and Social Inquiry 38 (1), 72-105.

Whelan, K., 2013. Target2 and central bank balance sheets. Economic Policy 29 (77), 79-137.

Zettelmeyer, J., Trebesch, C., Gulati, M., 2013. The greek debt restructuring: an autopsy. Economic Policy $28(75), 513-563$.

Zmijewski, M. E., 1984. Methodological issues related to the estimation of financial distress prediction models. Journal of Accounting Research 22, 59-82. 


\section{Appendix A. Merton model equations for pricing contingent claims}

Let us denote the observable value of the junior claims and its volatility by $V_{J}$ and $\sigma_{J}$ respectively and the fixed payment due at the end of the period $T$ as $S$. If we assume this simple capital structure for the entity and ignore market imperfections (like dividend payouts, short selling restrictions, etc.), then at time $t(0 \leq t \leq T)$, the value of the entity's assets will be,

$$
A(t)=S(t)+V_{J}(t)
$$

If we assume that the entity's asset value follows geometric Brownian motion, then

$$
d A(t)=\mu_{A}(t) A(t) d t+\sigma_{A}(t) A(t) d W
$$

where $A$ is value of the asset, $\sigma_{A}$ its volatility, $\mu_{A}$ drift and $d W$ is a Wiener process.

Because at the end of the period, senior creditors will receive their payment first while whatever remains will go to junior claim holders, junior claims can be seen as a call option on the entity's asset. Therefore, using the Black-Scholes option pricing theory analogically, the value of junior claims will be

$$
V_{J}(t)=A(t) N\left(d_{1}\right)-S e^{-r(T-t)} N\left(d_{2}\right)
$$

Using Ito's formula one can show

$$
\sigma_{J}(t)=\left(\frac{A(t)}{V_{J}(t)}\right)\left(\frac{\partial V_{J}(t)}{\partial A(t)}\right) \sigma_{A}(t)
$$

where $d_{1}=\frac{\log \left(\frac{A(t)}{S}\right)+\left(r-0.5 \sigma_{A}(t)^{2}\right)(T-t)}{\sigma_{A}(t) \sqrt{T-t}}, d_{2}=d_{1}-\sigma_{A}(t) \sqrt{T-t}$ and $r$ is the risk-free interest rate at time t.

Thus, to find the unobservable value and volatility of the asset, we solve the non-linear system of equations A.4 and A.5. The system offers a single value for $A(t)$ and $\sigma_{A}(t)$.

$$
\begin{gathered}
f_{1}\left(V_{J}(t), \sigma_{J}(t)\right)=A(t) N\left(d_{1}\right)-S e^{-r(T-t)} N\left(d_{2}\right)-V_{J}(t)=0 \\
f_{2}\left(V_{J}(t), \sigma_{J}(t)\right)=\frac{A(t)}{V_{J}(t)} N\left(d_{1}\right) \sigma_{A}(t)-\sigma_{J}(t)=0
\end{gathered}
$$


Figure 1: DtD vs Gross debt-to-GDP

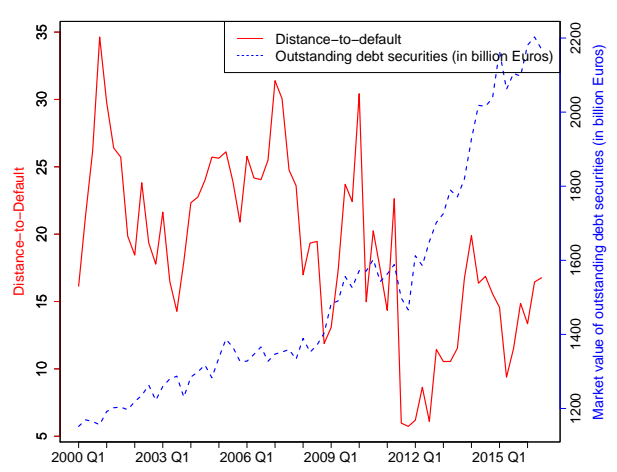

(a) Italy

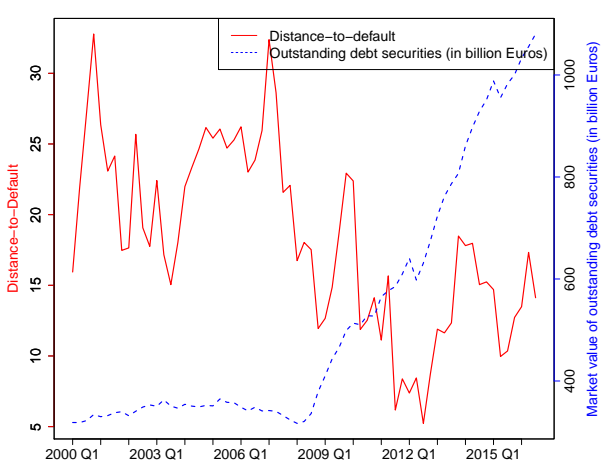

(b) Spain

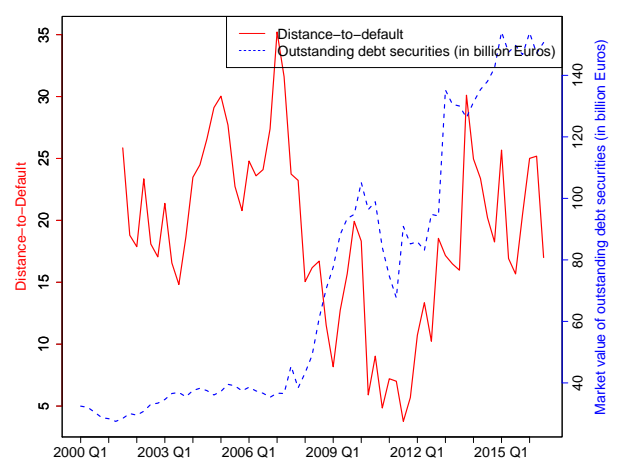

(c) Ireland

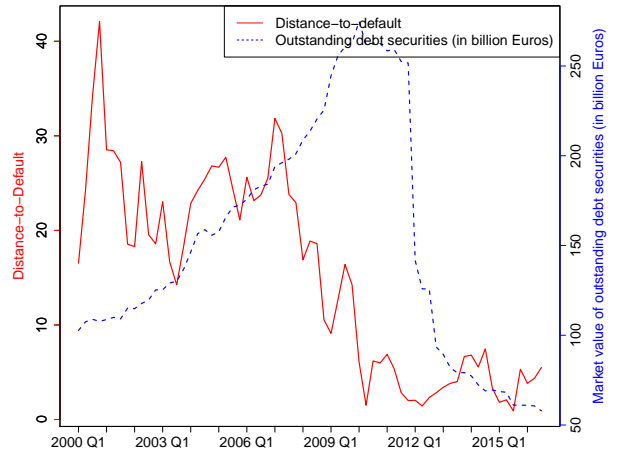

(d) Greece

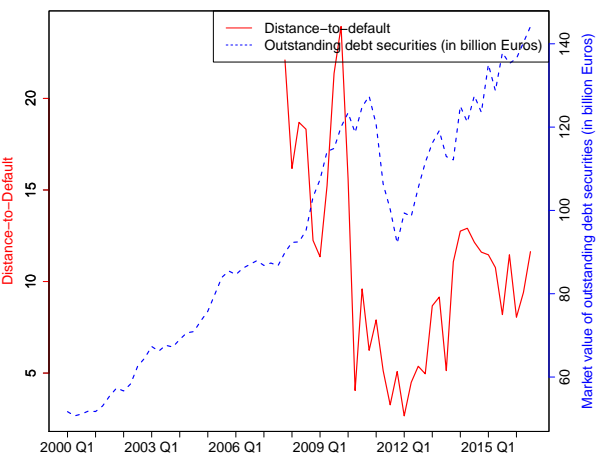

(e) Portugal

Note: The figure shows the evolution of general government gross debt as a percentage of GDP with sovereign DtD indices for individual peripheral EA countries. 
Figure 2: DtD vs Bond price volatility

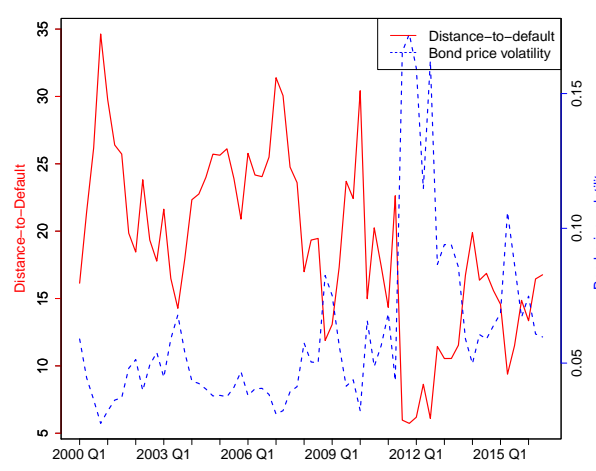

(a) Italy

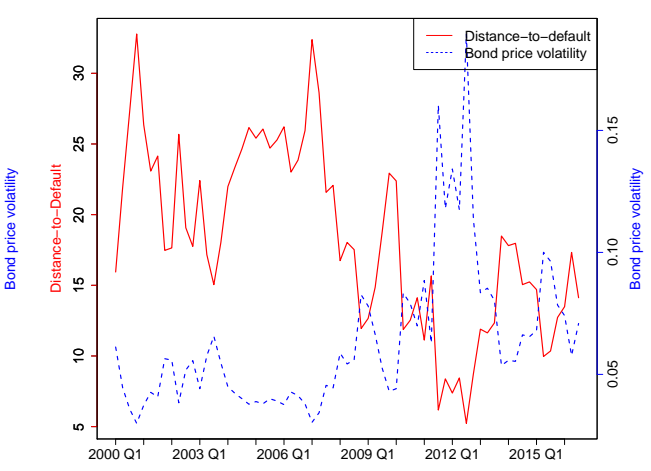

(b) Spain

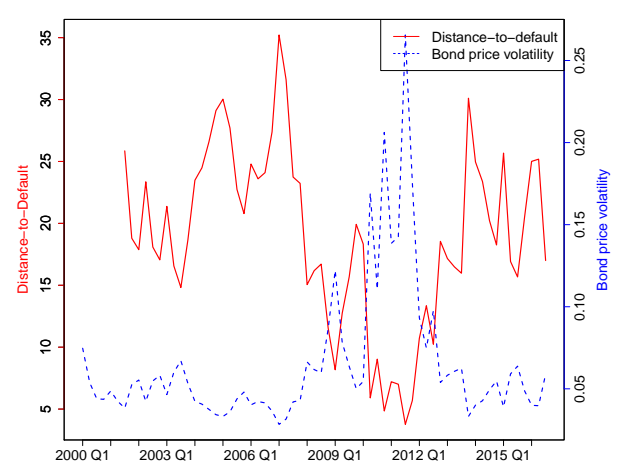

(c) Ireland

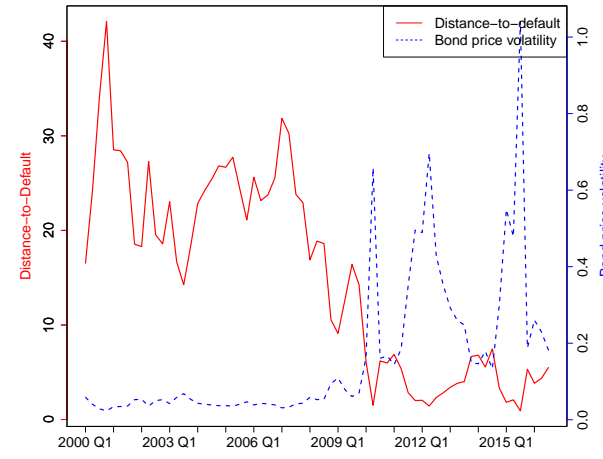

(d) Greece

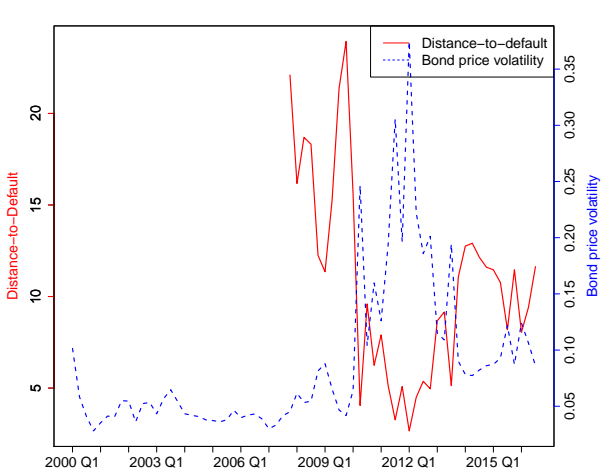

(e) Portugal

Note: The figure shows the evolution of sovereign's bond price volatility with sovereign DtD indices for individual peripheral EA countries. 
Figure 3: DtD vs Non-resident holding of government debt

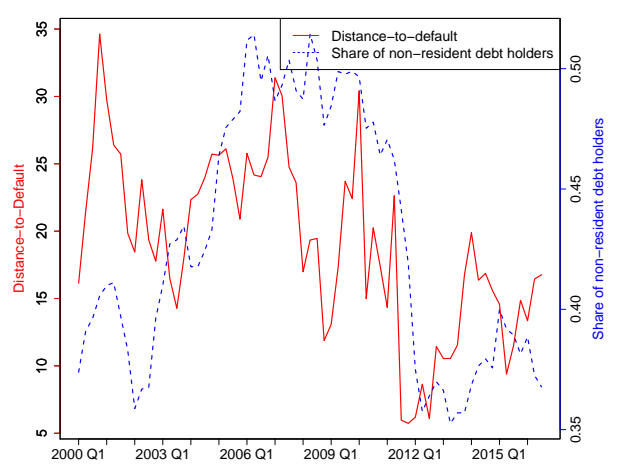

(a) Italy

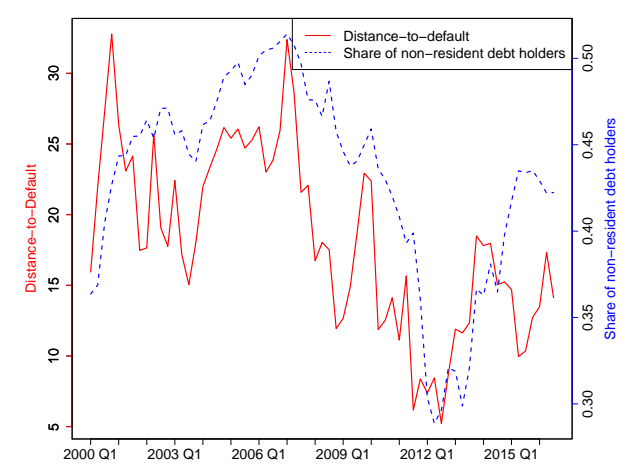

(b) Spain

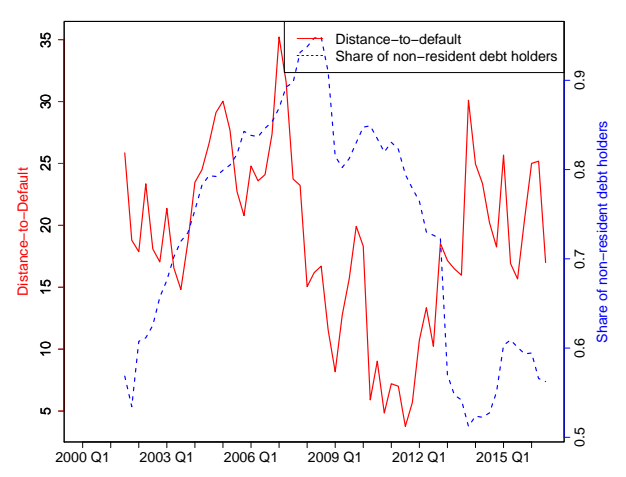

(c) Ireland

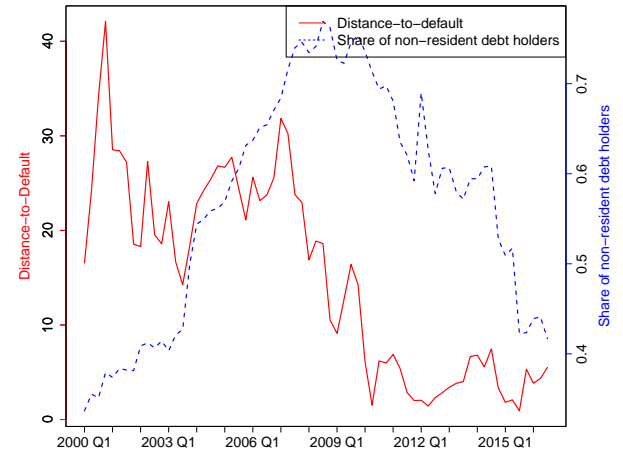

(d) Greece

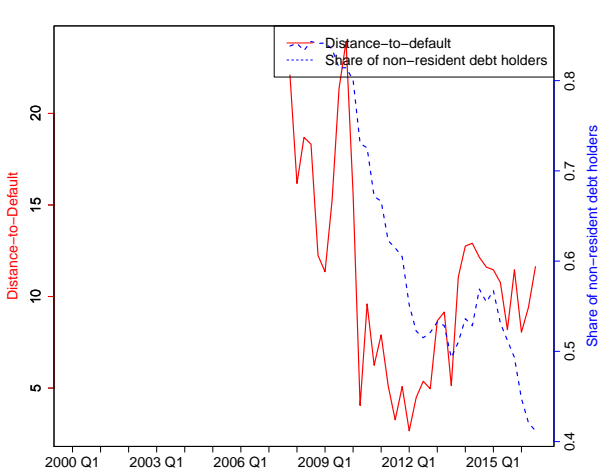

(e) Portugal

Note: The figure shows the evolution of the share of non-resident debt holding of general government gross debt with sovereign DtD indices for individual peripheral EA countries. 
Figure 4: DtD vs sovereign yield spreads

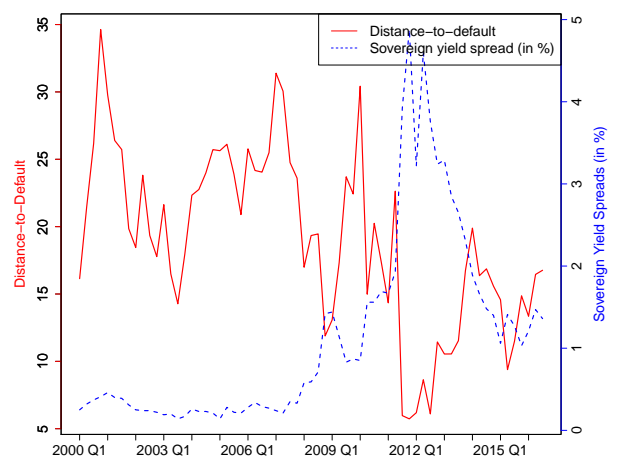

(a) Italy

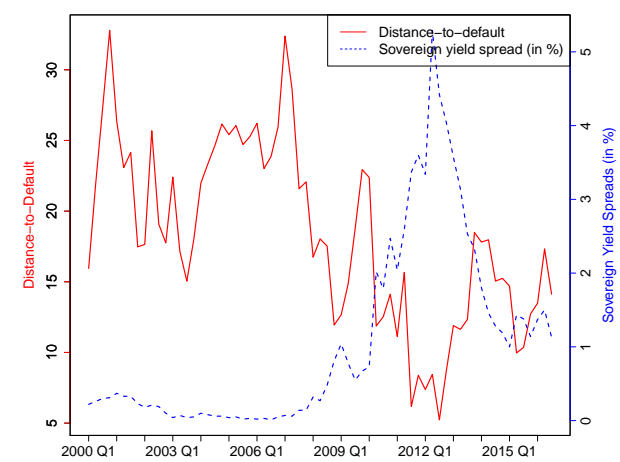

(b) Spain

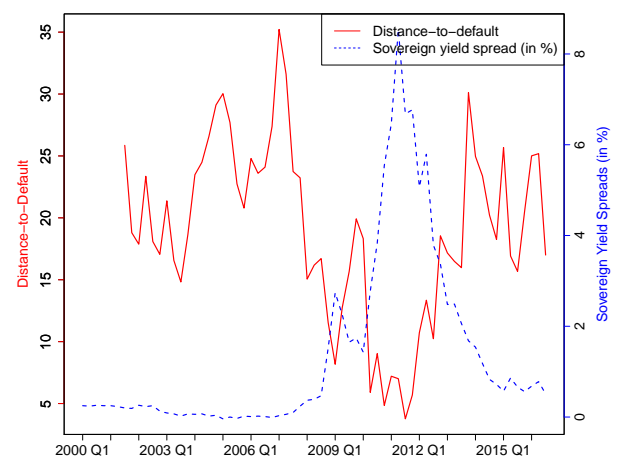

(c) Ireland

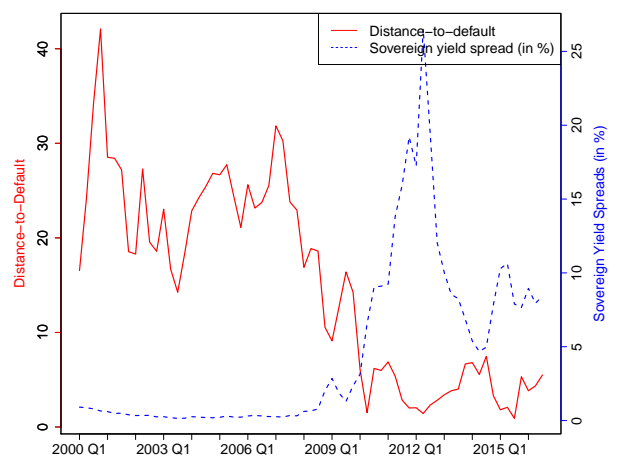

(d) Greece

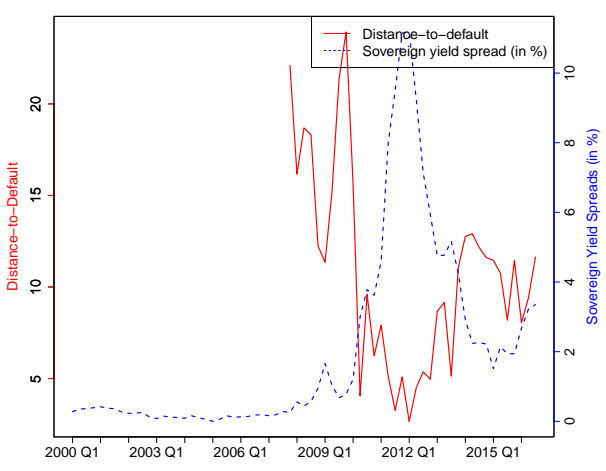

(e) Portugal

Note: Yield spreads are based on the Maastricht criterion bond yields (long-term interest rates) data provided by Eurostat. These are the rates used as a convergence criterion for the EMU, based on the Maastricht Treaty. The series relates to interest rates for long-term government bonds denominated in national currencies. The data are based on central government bond yields on the secondary market, gross of tax, with a residual maturity of around 10 years. Yield spreads are calculated as the difference between ten-year benchmark sovereign bond yield of each individual country and that of Germany. 
Figure 5: DtD vs 5-year benchmark sovereign CDS spreads

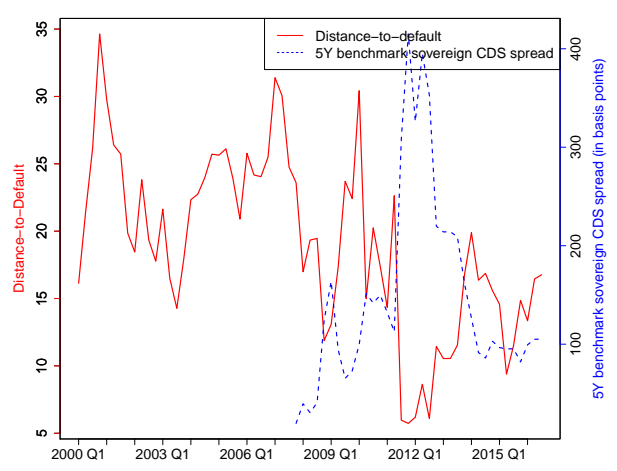

(a) Italy

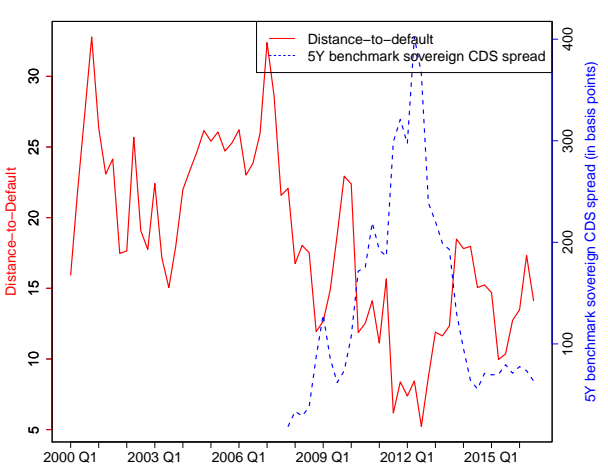

(b) Spain

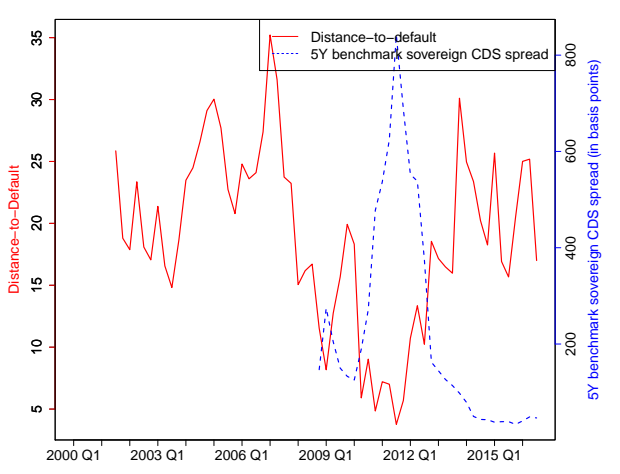

(c) Ireland

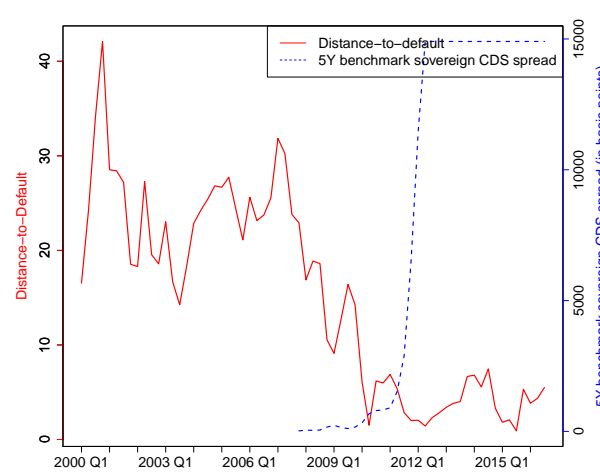

(d) Greece

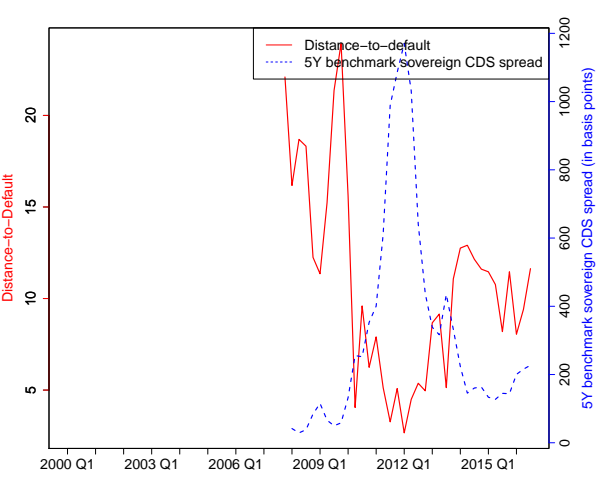

(e) Portugal

Note: The five-year benchmark sovereign CDS spreads data are available starting from 2007Q4. The Greek CDS spreads post the 2012 Greek debt restructuring experience are not reliable. Source: Datastream. 
Figure 6: DtD vs sovereign credit rating

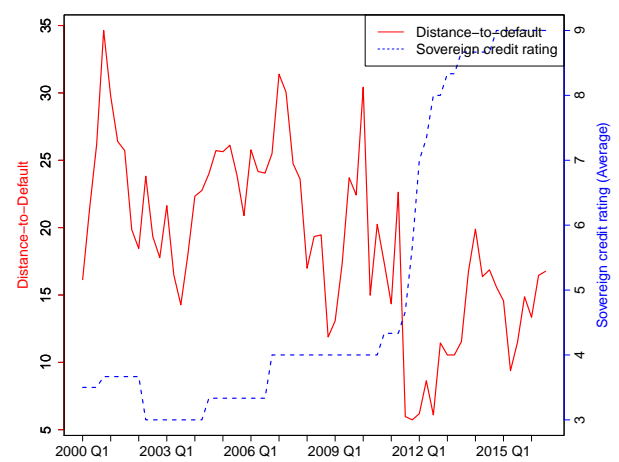

(a) Italy

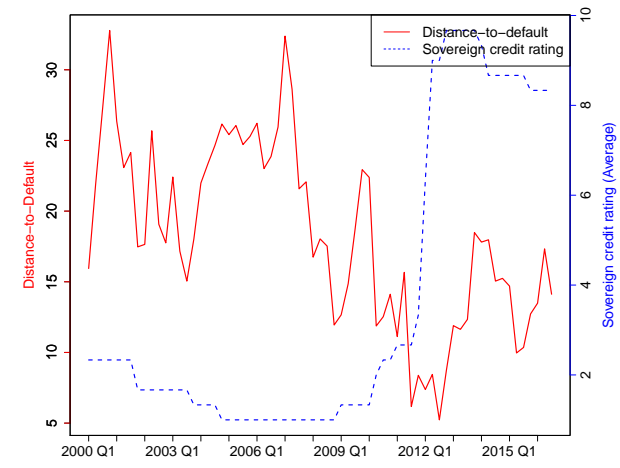

(b) Spain

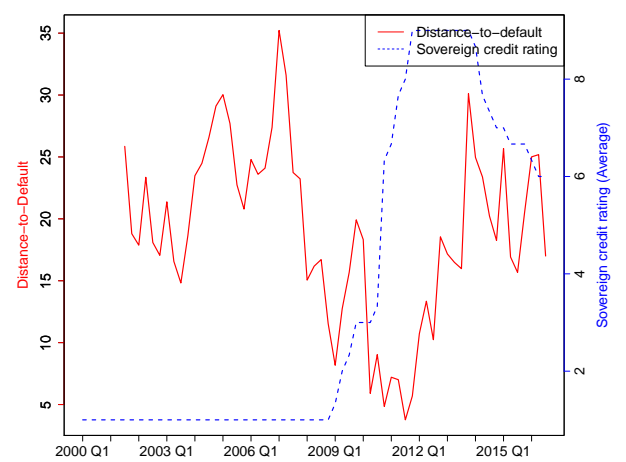

(c) Ireland

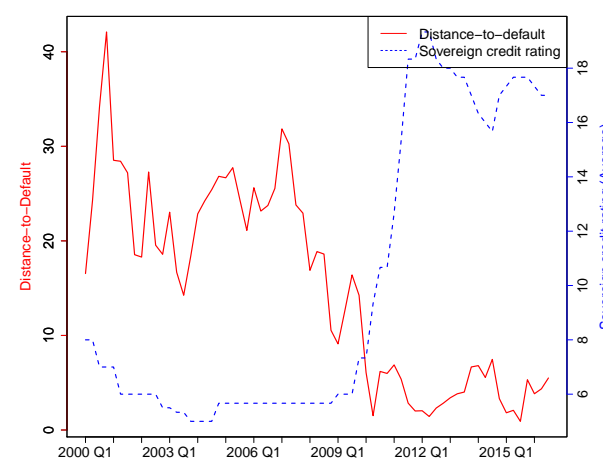

(d) Greece

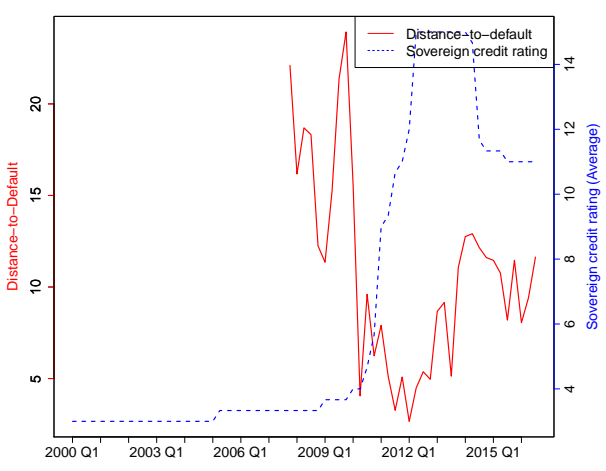

(e) Portugal

Note: Credit ratings data are built by averaging the ratings assigned to sovereign debt by Standard \& Poor's, Moody's and Fitch. Using data compiled from Bloomberg, 21 different categories are considered. The first category is made up of highest-rated debts whereas the twenty first includes the lowest-rated debts. 
Figure 7: Principal components of sovereign DtD, CDS, yield spreads and credit ratings
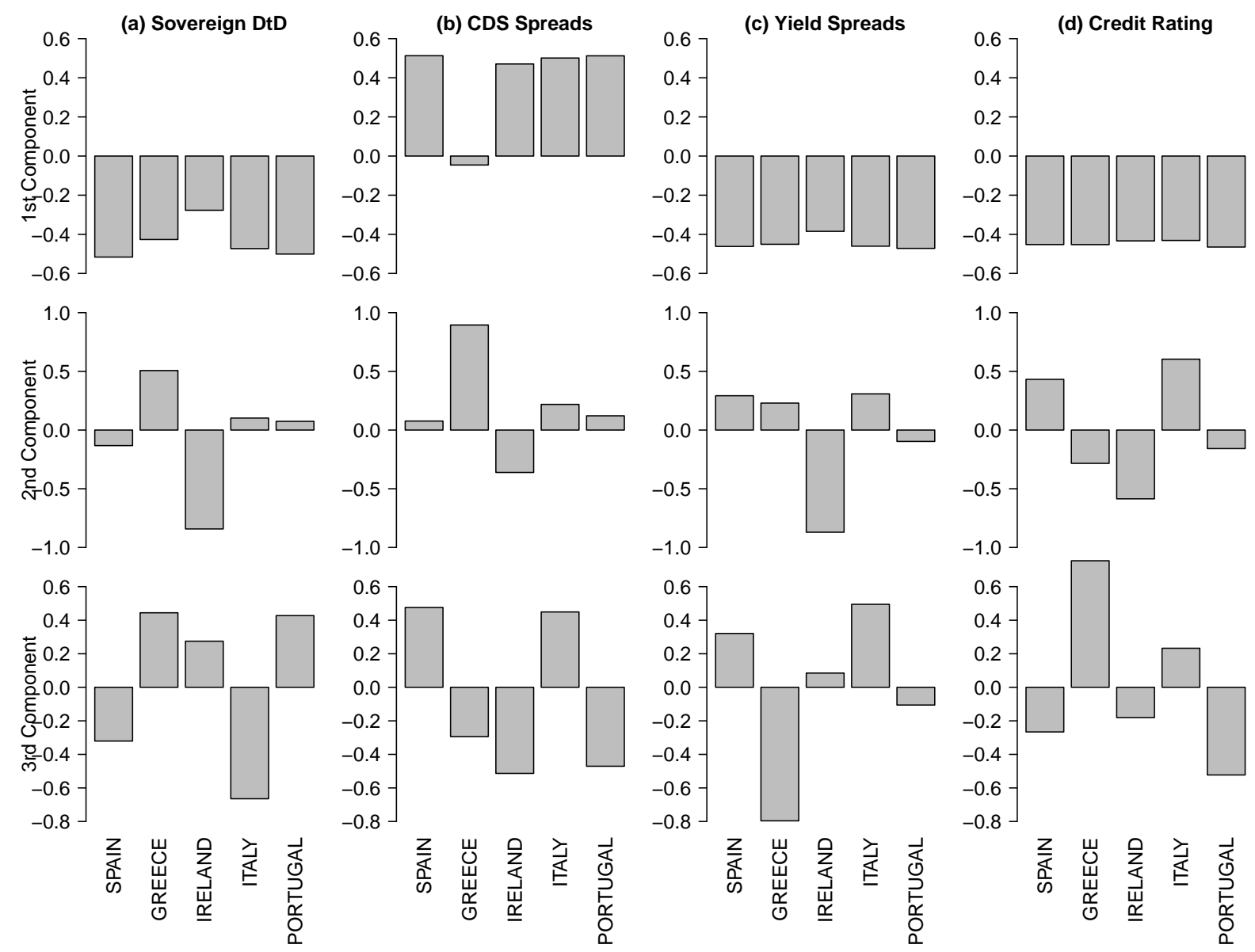

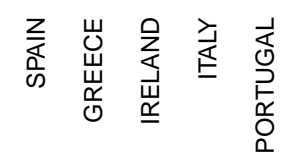

Notes: The figure shows the weighting vectors for the first three principal components for the sovereign DtD, CDS, yield spreads and credit ratings respectively for peripheral EA countries. The sample period is 2008Q4 to 2016Q3. This is the period for which we have the CDS, yields, ratings and sovereign DtD data for all countries. 
Figure 8: Generalized impulse-response functions: Sovereign DtD and sovereign yield spread

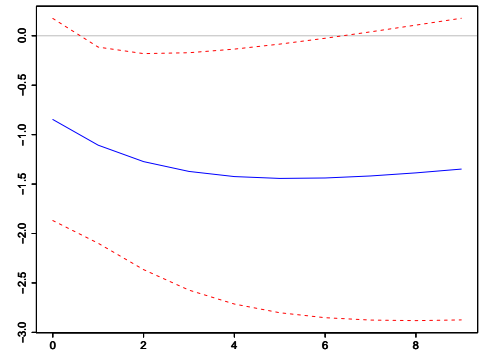

1a. Greece (Response of DtD to yield spread)

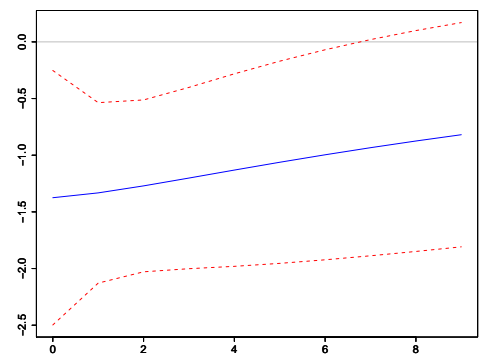

2a. Ireland (Response of DtD to yield spread)

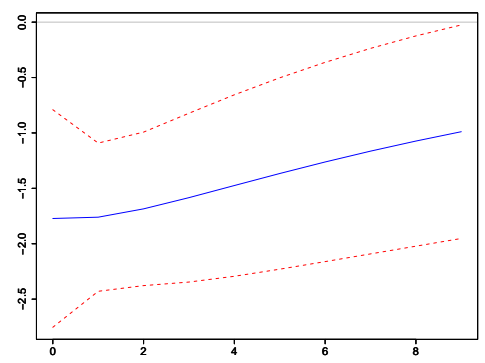

3a. Italy (Response of DtD to yield spread)

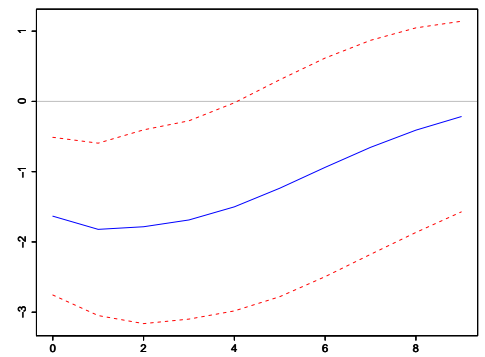

4a. Portugal (Response of DtD to yield spread)

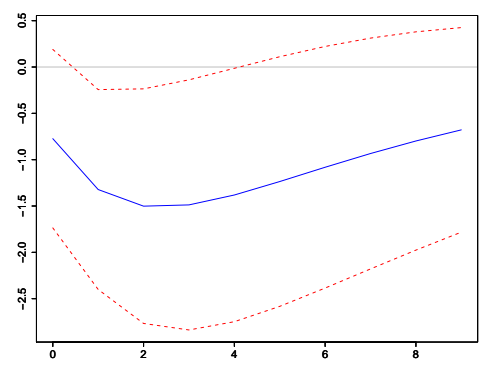

5a. Spain (Response of DtD to yield spread)

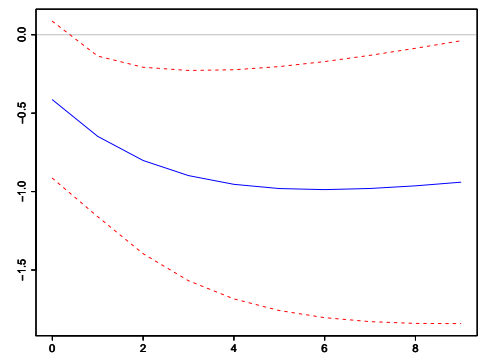

1b. Greece (Response of yield spread to DtD)

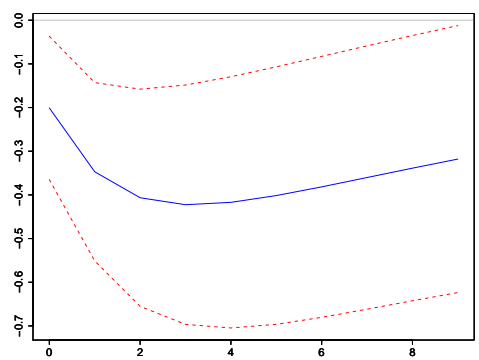

2b. Ireland (Response of yield spread to DtD)

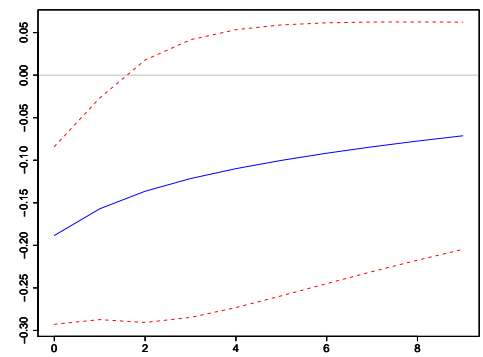

3b. Italy (Response of yield spread to DtD)

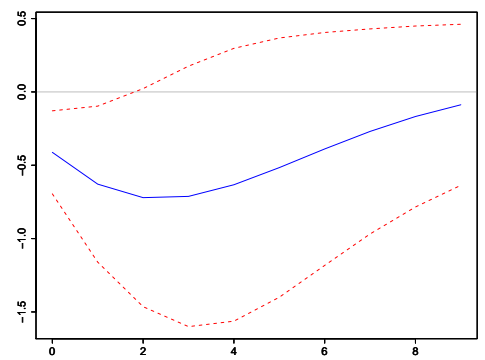

4b. Portugal (Response of yield spread to DtD)

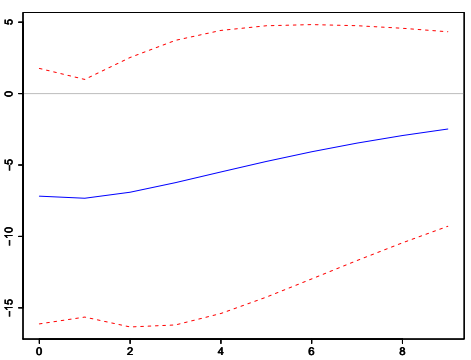

5b. Spain (Response of yield spread to DtD) Notes: Standard error bands are computed using analytic respond standard errors. 
Figure 9: Generalized impulse-response functions: Sovereign DtD and sovereign CDS spread

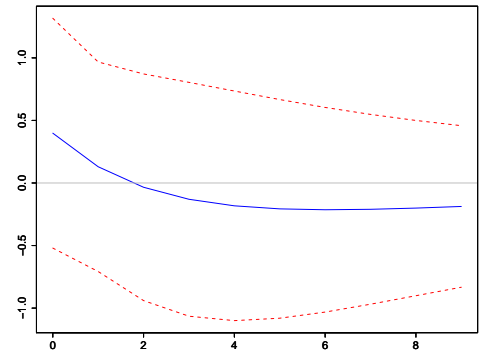

1a. Greece (Response of DtD to CDS spread)

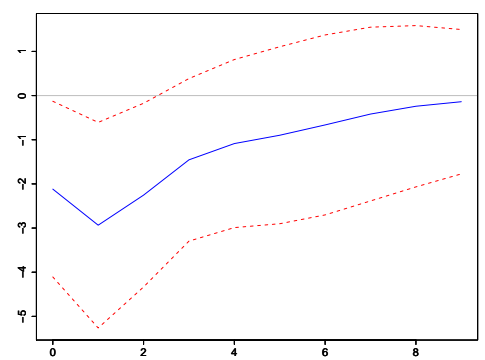

2a. Ireland (Response of DtD to CDS spread)

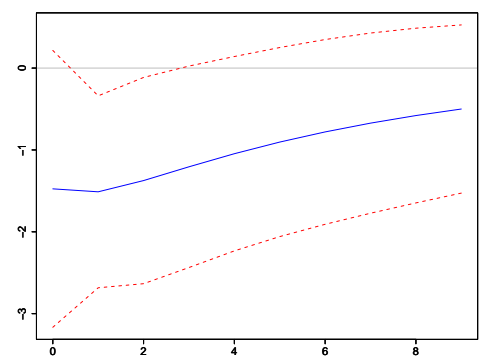

3a. Italy (Response of DtD to CDS spread)

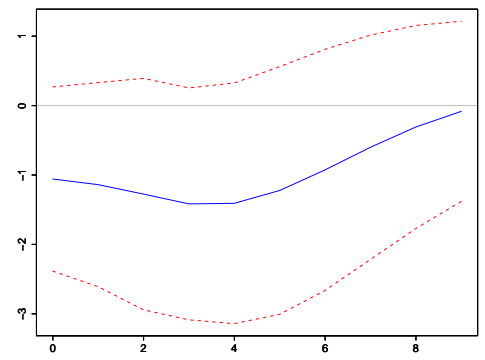

4a. Portugal (Response of DtD to CDS spread)

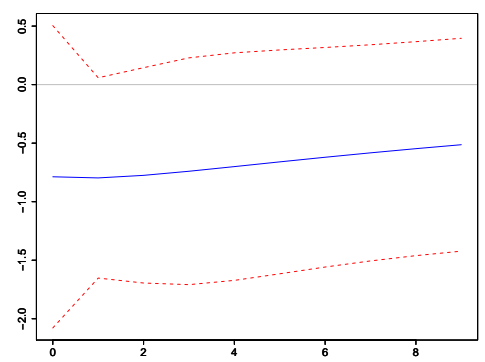

5a. Spain (Response of DtD to CDS spread)

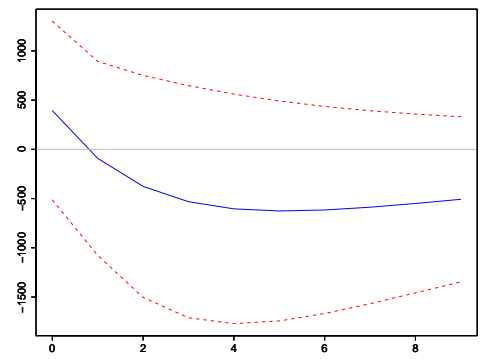

1b. Greece (Response of CDS spread to DtD)

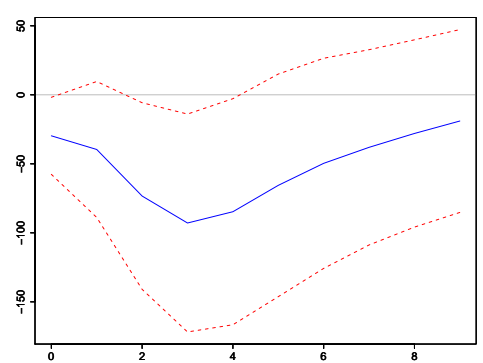

2b. Ireland (Response of CDS spread to DtD)

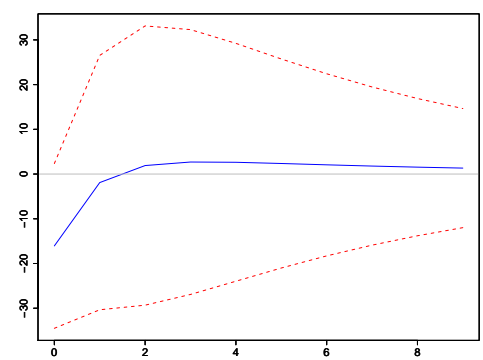

3b. Italy (Response of CDS spread to DtD)

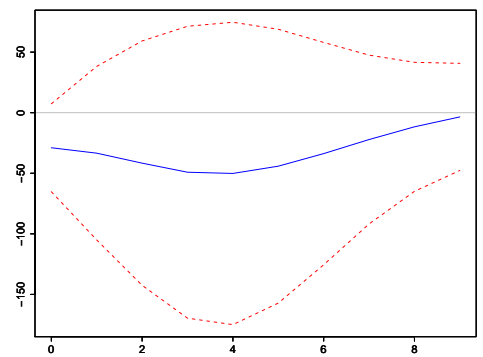

4b. Portugal (Response of CDS spread to DtD)

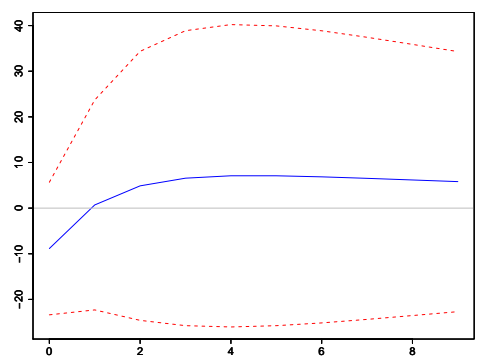

5b. Spain (Response of CDS spread to DtD) Notes: Standard error bands are computed using analytic respond standard errors. 
Figure 10: Generalized impulse-response functions: Sovereign DtD and sovereign credit rating

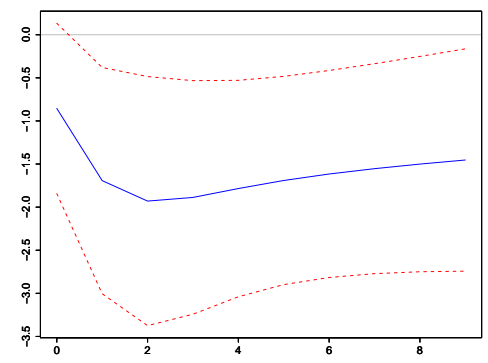

1a. Greece (Response of DtD to Credit Rating)

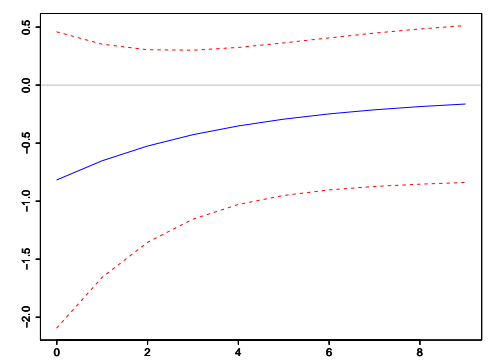

2a. Ireland (Response of DtD to Credit Rating)

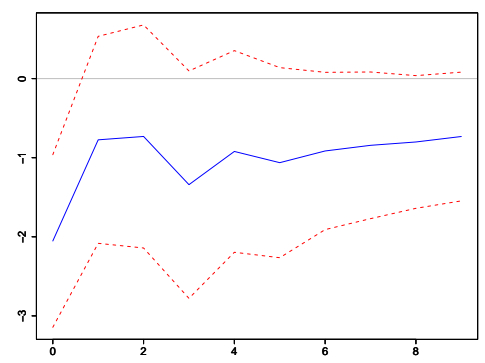

3a. Italy (Response of DtD to Credit Rating)

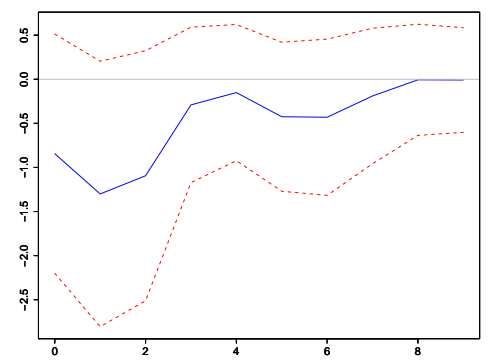

4a. Portugal (Response of DtD to Credit Rating)

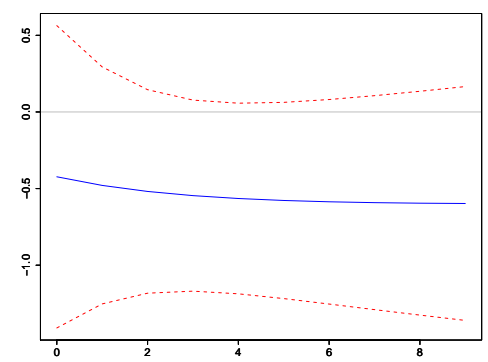

5a. Spain (Response of DtD to Credit Rating)

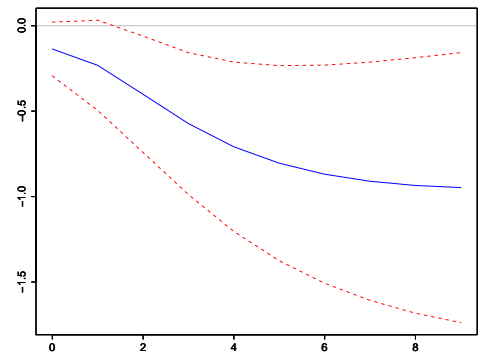

1b. Greece (Response of Credit Rating to DtD)

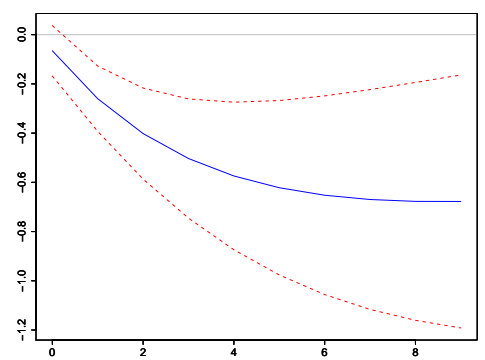

2b. Ireland (Response of Credit Rating to DtD)

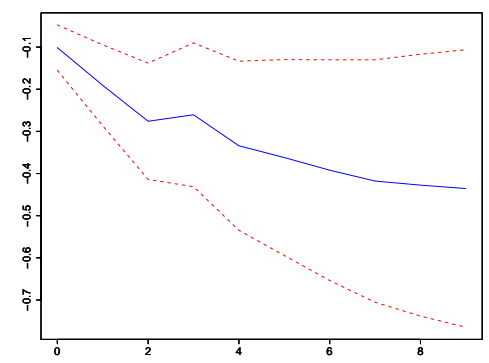

3b. Italy (Response of Credit Rating to DtD)

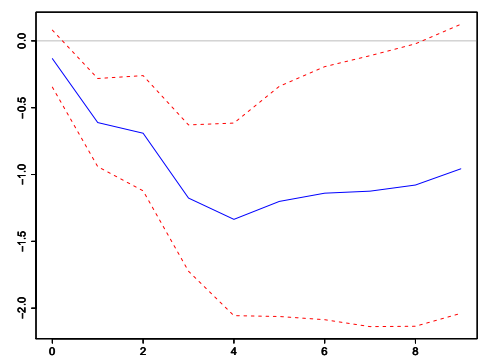

4b. Portugal (Response of Credit Rating to DtD)
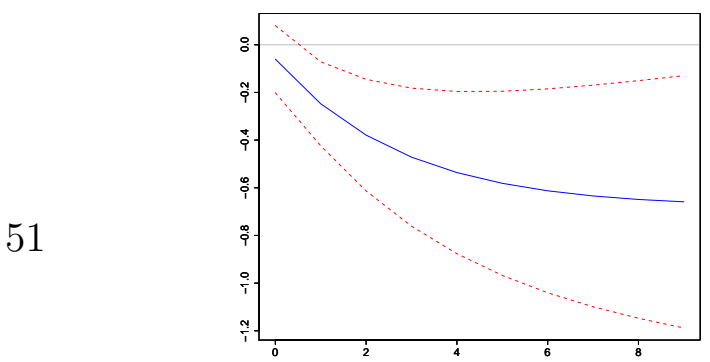

5b. Spain (Response of Credit Rating to DtD) Notes: Standard error bands are computed using analytic respond standard errors. 
Figure 11: Country-wise net pairwise directional connectedness between sovereign risk indicators

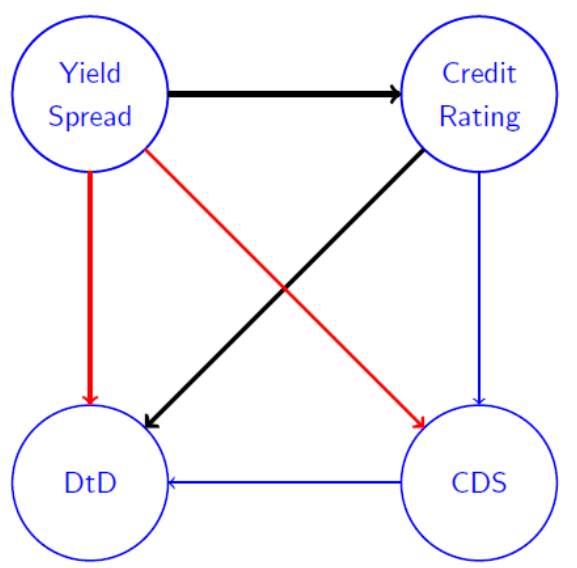

(a) Greece

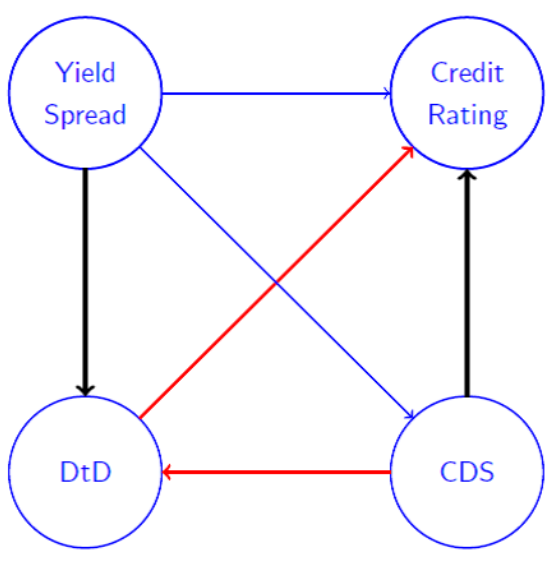

(b) Italy

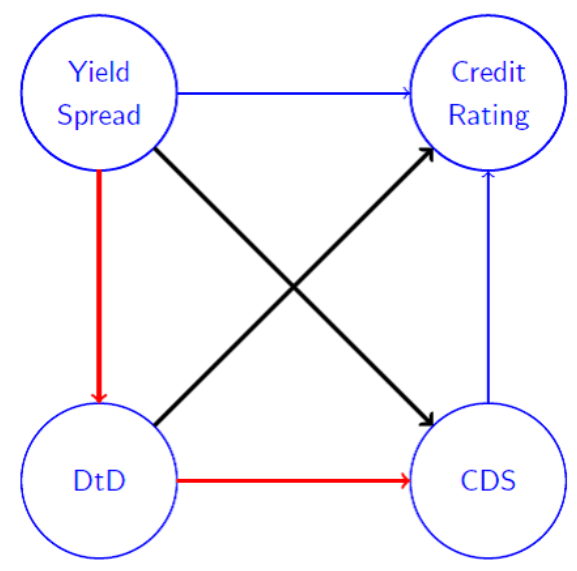

(c) Ireland

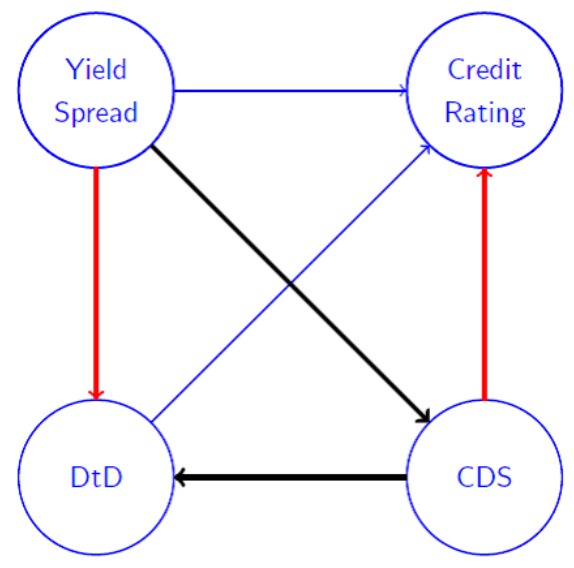

(d) Portugal

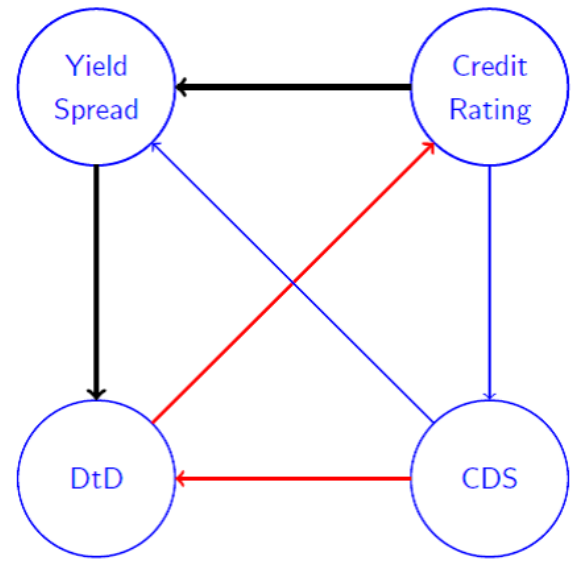

(e) Spain

Notes: To reflect the intensity of the relationship, we use black, red and blue links for very strong, medium and weak intensity. For each country, we first order the computed net directional connectedness values from the highest to the smallest and find the two points that divide the ordered distribution into three parts, each containing a third of the population. 


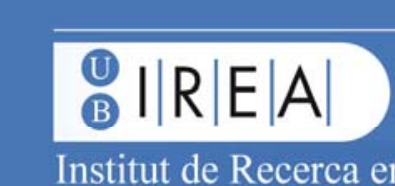

